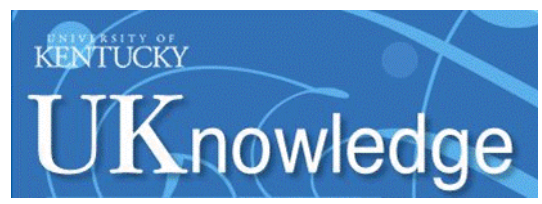

University of Kentucky

UKnowledge

\title{
Language Ideology and Racial Inequality: Competing Functions of Spanish in an Anglo-owned Mexican Restaurant
}

Rusty Barrett

University of Kentucky, erbarr2@email.uky.edu

Follow this and additional works at: https://uknowledge.uky.edu/lin_facpub

Part of the Linguistics Commons

Right click to open a feedback form in a new tab to let us know how this document benefits you.

\section{Repository Citation}

Barrett, Rusty, "Language Ideology and Racial Inequality: Competing Functions of Spanish in an Angloowned Mexican Restaurant" (2006). Linguistics Faculty Publications. 10.

https://uknowledge.uky.edu/lin_facpub/10

This Article is brought to you for free and open access by the Linguistics at UKnowledge. It has been accepted for inclusion in Linguistics Faculty Publications by an authorized administrator of UKnowledge. For more information, please contact UKnowledge@lsv.uky.edu. 
Language Ideology and Racial Inequality: Competing Functions of Spanish in an Anglo-owned Mexican Restaurant

Digital Object Identifier (DOI)

$10.1017 /$ S0047404506060088 


\title{
Language ideology and racial inequality: Competing functions of Spanish in an Anglo-owned Mexican restaurant
}

\author{
R U S T B A R R T T \\ Department of Linguistics \\ University of Chicago \\ 1010 E. $59^{\text {th }}$ Street \\ Chicago, IL 60637 \\ rustyb@uchicago.edu
}

\section{A B S T R A C T}

This article examines the influence of language ideology on interactions between English-speaking Anglo and monolingual Spanish-speaking employees in an Anglo-owned Mexican restaurant in Texas. In directives to Spanishspeaking employees, Anglo managers typically use English with elements of Mock Spanish. Because the Anglo managers fail to question whether their limited use of Spanish is sufficient for communicative success, Spanish speakers are almost always held responsible for incidents resulting from miscommunication. For Latino workers, Spanish provides an alternative linguistic market in which Spanish operates as a form of solidarity and resistance. The competing functions of Spanish serve to reinforce racial segregation and inequality in the workplace. (Latinos, English/Spanish bilingualism, Mock Spanish, miscommunication, resistance, segregation, workplace.)*

\section{N T R O D U C T I O N}

This article examines the ways in which language ideology influences interactions between monolingual Spanish-speaking workers and Anglo (U.S. English speakers of European ancestry) managers and workers in a Mexican restaurant in Texas. Because of the widespread acceptability of "grossly non-standard and ungrammatical" Mock Spanish (Hill 1998:682), Anglo directives in Spanish (or in English with Mock Spanish elements) are often misinterpreted by Spanish speakers. The Anglos' disregard for producing grammatical (or even understandable) forms in Spanish shifts the communicative burden almost entirely to the Spanish speaker, who is often left with insufficient semantic content for interpreting Anglo speech. Anglo managers typically do not question whether their limited use of Spanish is sufficient for communicative success, and Anglos typically assume that the Spanish speakers are responsible for incidents resulting from miscommunication. A directive that fails (in that the requested act is done incorrectly or not done at all) is almost always interpreted on the 
basis of racist stereotypes of Spanish speakers as lazy, indignant, uncooperative, illiterate, or unintelligent. The Anglo use of Spanish marginalizes Spanish speakers within interactions, demonstrating a general disregard for Spanish speakers as cultural actors. The Anglo use of Mock Spanish to index a particular Anglo ethnic stance diminishes the ability of Spanish to serve a communicative function. The ideology of Mock Spanish reinforces racial inequality by restricting the agency of Latino workers.

In contrast, Spanish-speaking employees often use Spanish as a tool of solidarity and resistance. The fact that Anglos pay little attention to what is said in Spanish allows the Latino workers to use Spanish as a means of controlling resources in the restaurant. The lack of attention to Spanish also makes it possible for Spanish speakers to talk openly about (and sometimes mock) Anglo workers and managers, even when the referent is able to hear what is being said. Although Anglo uses of Spanish may be seen as ways of limiting the agency of Spanish speakers, Latino workers use Spanish to develop an alternative linguistic market in which individual agency may be asserted in different ways.

Hill 1998 argues that language ideology plays a role in delineating "white public space" through the use of varieties such as Mock Spanish (Hill 1993, 1995). In Mock Spanish, Anglo speakers incorporate Spanish words into otherwise English discourse to "create a jocular or pejorative 'key" (Hill 1998:682). Hill (1998:682-83) lists the following strategies found in Mock Spanish:

Semantic pejoration of Spanish words - the use of positive or neutral Spanish words in humorous or negative contexts (e.g., nada to mean "less than nothing" peso to convey "cheap")

Mock Spanish euphemism - the use of obscene or scatological Spanish words in place of English equivalents (e.g., the use of cojones)

The use of Spanish grammatical elements - the addition of the "Spanish" suffix $+o$ to nouns and the use of the definite article el (e.g., el cheapo)

Hyperanglicization - parodic pronunciations and orthographic representations that reflect an exaggerated English phonology (e.g. Fleas Navidad on a Christmas card).

These strategies of Mock Spanish are used in Anglo speech designed for Anglo audiences and typically index racist stereotypes of Latinos. Although Mock Spanish usually carries a negative message, speakers of Mock Spanish are likely to view their use of Spanish as indexing positive personal qualities:

Mock Spanish accomplishes the "elevation of whiteness" in two ways: first, through directly indexing valuable and congenial personal qualities of speakers, but importantly, also by the same type of indirect indexicality that is the source of its negative and racializing messages. It is through indirect indexicality that using Mock Spanish constructs "White public space," an arena in which linguistic disorder on the part of Whites is rendered invisible and nor- 
mative, while the linguistic behavior of historically Spanish-speaking populations is highly visible and the object of constant monitoring. (Hill 1998:684)

In the context of a linguistic marketplace where Spanish is undervalued, Anglo use of Mock Spanish in interactions with Latinos serves as a "strategy of condescension" (Bourdieu 1991). Because Spanish is racialized to be an iconic marker of Latino ethnic identity (cf. Urciuoli 1996:15-40), the presence of any Spanish (even grossly distorted or obscene Spanish) indexes an acknowledgment of the racial difference in an interaction. Although the use of Mock Spanish often does little more than index the race of a Latino interlocutor, Anglos may interpret the use of any Spanish at all as an index of egalitarian attitudes toward Latinos and, by extension, general sympathy with minority groups. Speakers of Mock Spanish may thus produce offensive racialized meanings while simultaneously interpreting their utterances as a reflection of an open-minded (explicitly nonracist) point of view.

In the interactions presented in this paper, the language ideology of Mock Spanish leads to inequality in the communicative burden between native and nonnative speakers of English (Lippi-Green 1997, Lindeman 2002, Perkins \& Milroy 1997). While Spanish speakers must carefully monitor their use of both Spanish and English to ensure that they will be listened to, Anglo English speakers regularly produce ungrammatical and offensive forms of Spanish with no concern for how this Spanish might be perceived by actual Spanish speakers (cf. Hill 1993, 1995, 1998).

\section{Mock Spanish as linguistic appropriation}

Hill's groundbreaking work on Mock Spanish has inspired linguists to pay closer attention to Mock varieties (cf. Ronkin \& Karn 1999, Mesthrie 2002, Chun 2004). All of these Mock varieties have certain common traits. They all reduce the grammar of the mocked variety to a stereotyped representation of the language. Mock varieties also index racist ideologies and reinscribe racist stereotypes, operating as forms of symbolic revalorization (Woolard \& Schieffelin 1994, Walters 1995), in which attitudes toward particular language varieties stand in for (proscribed) expressions of racial or ethnic prejudice. Mock Ebonics (Ronkin \& Karn 1999), for example, is typically used to reproduce racist humor directed against "speakers of Ebonics" rather than "African Americans." The racist nature of Mock Ebonics and Mock Asian (Chun 2004) is fairly transparent. The use of Mock Asian forms such as ching-chong-ching-chong (Chun 2004) to an Asian American is likely to be understood as a form of hate speech. The racist nature of Mock Spanish is covert, however, so that Anglos typically see their use of it as humorous, indexing a positive social identity (Hill 1998:683).

Despite its name, Mock Spanish may be better understood as an example of appropriation and not generally a form of overt mocking. Although Hill compares Mock Spanish to the crossover of words from African American English 
(AAE) into White English, she claims that the two cases are quite different. In actual usage, however, Mock Spanish is in many ways much closer to AAE crossover than to other Mock varieties. For example, Hill notes that Mock Spanish may be used in discourse unrelated to race and in speech to apparent Spanish speakers (1998:684). While Mock Ebonics and Mock Asian are overtly mocking racial caricatures, Mock Spanish patterns more like AAE crossover in that its context-of-occurrence is largely unrestricted. For example, white speakers may just as well say Whassup? to an apparent speaker of AAE as they would say ¿Que pasa? to an apparent speaker of Spanish.

The label (or misnomer) "Mock Spanish" obscures the importance of Anglo Spanish as a form of linguistic appropriation. Hill recognizes the affinity between white appropriation of AAE and Mock Spanish, but she argues that AAE and White English are so "thoroughly entwined" that white usage of AAE is often indeterminate (1998:685). Words from AAE are readily borrowed into white usage, quickly losing their indexical association with speakers of AAE (cf. Smitherman 1994; Morgan 2001, 2002; Bucholtz 2004). Mock Spanish forms, however, are easily recognized as "Spanish" and maintain their indexical association with Spanish speakers. This difference is quite important in understanding both forms of appropriation, but the distinction might also simply result from the fact that AAE crossover is a form of dialect borrowing, while Mock Spanish involves borrowing from another language. Hill's focus on the difference between the two forms of appropriation fails to highlight their numerous similarities.

The affinity between these two forms of appropriation can be illustrated with Hill's example of the use of Mock Spanish in the film Terminator II: Judgment Day. In teaching the Terminator "the way people talk," the child John Connor mixes Mock Spanish with other forms of slang, including the AAE crossover to chill:

(1) From Terminator II: Judgment Day (Cameron \& Wisher 1991)

John Connor: You gotta listen to the way people talk. You don't say "affirmative" or some shit like that. You say, "No problemo." And if someone comes off to you with an attitude, you say "Eat me." And if you want to shine them on it's "Hasta la vista, baby."

Terminator: Hasta la vista, baby.

John Connor: Yea, "Later dickwad." And if someone gets upset, you say "Chill out"

The phrase chill out is a fairly recent (i.e., probably not indeterminate in 1991) appropriation from AAE (cf. Smitherman 1994:78). In the Terminator's crash course in language socialization, Mock Spanish is linked both to AAE crossover and to more general "slang" forms such as Eat me.

Bucholtz 2004 argues that young white speakers see their use of AAE as the introduction of new slang forms, and not as something like second-dialect acquisition. The slang dictionary at urbandictionary.com (cf. Bucholtz 2004), which invites individuals to submit examples of slang, contains numerous examples of both AAE and Spanish appropriations. Spanish words submitted as slang in- 
clude Mock Spanish standards such as nada, hasta la vista, and cojones as well as examples such as chica 'girl', hombre 'man', and madre 'mother'. ${ }^{1}$ Eble (2004:376) defines slang as "deliberate alternative vocabulary that sends social signals," noting that slang vocabulary "rarely refers to meanings that the ordinary vocabulary does not have words to express" (2004:377). AAE crossover terms and Mock Spanish may both serve the same functions as general slang vocabulary. Appropriated terms serve as alternatives to "regular" vocabulary that may be used to index social affect. Thus, it is not surprising that speakers who visit urbandictionary.com freely submit forms from both AAE and Spanish as examples of what they see as "slang."

Bucholtz demonstrates that for some young white speakers, the simple addition of the article $d a$ to a noun may create a new slang form. Lexical entries submitted to urbandictionary.com include an abundance of $d a$-formations, including da club, da band, da fuck, da cheese, and da sex. The da is adopted from a stereotype of the AAE pronunciation of the with an initial voiced stop and generalized from appropriated forms such as da man or da bomb. This use of $d a$ is identical to the use of the article $e l$ in Mock Spanish forms like el cheapo; indeed, the slang entries at urbandictionary.com include numerous cases of elformations, many with the additional $+o$ suffix. Examples include el asso bandito, el pervert, el hobo, el homo, el bitcho, and el bastard ("more of a bastard than the normal bastard"). In all these examples, the addition of a racially marked definite article ( $d a$ or $e l$ ) creates what white speakers understand as a new, alternative slang noun. As with AAE, the ideology of Spanish as colloquial or "slangy" licenses Anglo norms for the use of appropriated forms.

\section{Theoretical background}

Hill's examples of Mock Spanish are Anglo productions for Anglo audiences. In the data presented here, however, Anglos often use Mock Spanish with Spanish speakers. Anglo speakers who know enough Spanish grammar to produce "real" Spanish do not fully utilize their knowledge of Spanish when communicating with Spanish speakers. The exploitation of the indexical meanings associated with Mock Spanish interferes with the communicative function of Spanish in interactions between native Spanish speakers and Spanish-speaking Anglos.

Silverstein (1998:129) suggests a view of language ideologies as "invokable schemata in which to explain/interpret the meaningful flow of indexicals." Indexical signs presuppose or entail (create) a particular context-of-occurrence (Silverstein 1992). The use of particular indexicals is performative (Austin 1962) in that it creates a particular context. The felicity of performatively asserting a context-of-occurrence depends on shared norms for interpreting indexical signs as markers of particular functions for language use (Hymes 1974, Jakobson 1960). The context-of-occurrence may involve indexicals that serve multiple functions. 
The use of indexicals to create social contexts also involves the projection of particular speaker identities and stances and the establishment of social relationships between participants. The contextual functions of an indexical are inseparable from its expressive and phatic functions.

As with stereotypical performatives like promises and pronouncements, whether or not a performative indexical succeeds (or is felicitous) depends on participants' shared recognition of the indexical as a citation and on their acceptance of the speakers' authority to convey a particular indexical meaning. For indexical meanings to create a particular social context, the listener(s) must be aware of the indexical and its relationship to a given context-of-occurrence. Because speakers may not share norms for interpreting particular indexical signs, the creation of a context-of-occurrence may not succeed. As Ochs notes:

It is important to distinguish the range of situational dimensions that a form (set of forms) potentially indexes from the range of situational dimensions that a form (set of forms) actually indexes in a particular instance of use (in the mind of any participating interlocutor - speaker, addressee, overhearer, etc). The indexical potential of a form derives from a history of usage and cultural expectations surrounding that form. When a form is put to use in dia$\log$, the range of situational dimensions that particular form indirectly helps to constitute and index is configured in a particular way. Not all situational meanings are necessarily entailed. (Ochs 1996:418)

In a case where speakers do not share cultural expectations concerning the indexical potential of a given form, an indexical may fail to create the intended social context. Participants may interpret indexical signs according to different cultural expectations, including different interpretations of the functions particular indexical meanings may perform. Different expectations for interpreting indexical signs typically result in cross-cultural miscommunication (e.g. Gumperz 1982). It is important to recognize, however, that indexical meanings are interpreted in terms of language ideologies. Because language ideologies are often a reflection of racial ideologies (as in symbolic revalorization), indexical meanings are often interpreted in terms of racial ideologies as well.

Because a context-of-occurrence involves relationships between participants, speakers may use the performative force of indexical signs to assert a particular relational status with regard to other participants. Speakers may use indexicals to create a context-of-occurrence that entails a position of power by encoding restrictions on the agency of another participant (or referent). The interpretation of indexical meanings may enact racial difference (and racial inequality) in the context of a given interaction. Speakers may employ indexicality as a means of enacting social inequality, but they may also use indexical meanings as a tool of solidarity or resistance. 
The enactment of racial inequality in a given interaction may be understood in terms of struggles over the agency of individual cultural actors (Ahearn 2001; Duranti 2001, 2003). Duranti defines agency as

the property of entities

i) that have some degree of control over their own behavior

ii) whose actions in the world affect other entities (and sometimes their own), and

iii) whose actions are the object of evaluation (Duranti 2001:269)

These aspects of agency are useful for understanding the ways in which language ideologies may enact social inequalities such as racial discrimination. For example, a standard language ideology that presumes an inherently superior standard dialect produces negative evaluations that restrict the opportunities open to speakers of nonstandard varieties.

Forms of linguistic appropriation like Mock Spanish can be seen as attempts to control the norms for interpreting indexical meanings. Appropriating the language of another group undermines the indexical association between linguistic form and speaker identity. Appropriation asserts control over the norms for evaluating utterances, typically interfering with the evaluative norms held by speakers of the source language. Anglo appropriation of lexical items from AAE, for example, undermines the indexical association between AAE and African American identity. One response to appropriation is that speakers continually produce new and innovative forms that reinstate the indexical meanings lost through appropriation, a strategy that Morgan (2001, 2002) has called "lexical havoc." Appropriation imposes Anglo interpretations of indexicality, restricting the ability of Spanish (or AAE) speakers to performatively enact particular contextsof-occurrence because the customary use of indexicality may turn out to be infelicitous in interactions with Anglo speakers. The ability to affect other speakers may be diminished by appropriation because the performative force of particular signs in enacting particular interactional contexts depends on indexical meanings that may no longer be valid after their associated signs have been appropriated by Anglo speakers.

Because language ideology is a schema for understanding the performative potential for indexical meanings to create particular social alignments in a given interaction, it may serve to enact social ideologies by performatively entailing social contexts that place speakers from dominating groups in positions of relative power. In the examples presented in this article, for example, Anglos typically use Spanish to invoke the indexical meanings associated with Mock Spanish as a marker of Anglo social identity or social affect. For monolingual Spanish listeners, however, this indexical meaning is not entailed, and the "disorderly" use of Spanish is typically interpreted as an inability or unwillingness to speak Spanish. In such interactions, Anglo speakers disregard the referential function 
of Spanish in favor of the metalingual and emotive functions associated with Mock Spanish as a marker of Anglo identity.

CHALUPATOWN RESTAURANT ${ }^{2}$

Chalupatown is an Anglo-owned Mexican restaurant in Texas. The restaurant seats approximately 200 dining customers with a bar/waiting area that seats an additional 100 customers. Chalupatown is a successful restaurant with a clientele which is overwhelmingly middle-class and Anglo. My research at Chalupatown was conducted over the course of three years, when I worked there full-time - primarily as a bartender and occasionally as a server. The data were collected during the third year, after I had finished my Ph.D. and continued working in the restaurant while searching for an academic position.

Lindquist $(2002,2004)$ argues that bartenders are naturally occurring ethnographers because of their status as participant-observers in the social life surrounding the bar itself. That is, bartenders are simultaneously central to and removed from the social action of the surrounding bar (Lindquist 2002:300). A bartender holds an integral position in the culture of the bar and is central to interactions between customers. However, because bartenders are not actual customers, they maintain "outsider" status in relation to customers involved in bar culture. The position of restaurant bartenders is somewhat different from the position described by Lindquist of working in a bar. Restaurant bartenders are responsible for making drinks both for customers at the bar and for servers waiting on customers dining in the restaurant. The layout of Chalupatown included two bars, one for serving drinking customers and another for filling orders from servers. The back server bar was connected to a small wait station that connected the bar and the kitchen. Tickets for drink orders from servers would print out in the back bar, where the bartender would prepare the drinks and place them on the counter for servers to pick up. Because the bartender making drinks for servers worked right next to the wait station, interactions between servers and the bartender were quite frequent. During busy times, tickets would usually print continuously and servers frequently waited by the bar (either at the counter where drinks were given out or in the wait station) for their orders to be filled. The social relationship of the bartender working in the back bar was thus similar to that described by Lindquist, except that the interactions were with servers rather than with customers. Because the bar was some distance from the majority of customers, servers frequently used the area to hold discussions about their customers or activities occurring elsewhere in the restaurant.

Bartenders were also responsible for retrieving necessary supplies (liquor, carbon dioxide tanks, fruit for garnishing drinks, etc) from the kitchen and storerooms to ensure that both bars were fully stocked. The bartender working the day shift performed prep work for the night shift bartenders, such as slicing fruit to garnish drinks, conducting inventory, and restocking beer and liquor. All the 
items that the daytime bartender required were in a storeroom that could be reached only by passing through the kitchen. During day shifts, there were very few drink orders or bar customers, so the bartender spent a large part of the day working in the storeroom. Because the daytime bartender spent a lot of time in the back part of the restaurant, interactions during these shifts were primarily with the kitchen staff rather than with the servers.

During the three years that I worked at Chalupatown, I alternated positions but primarily worked in the back (server) bar at night and during day shifts. I thus had many more interactions with both servers and kitchen workers than with actual bar customers. Because the day bartender spent a large part of the day in the back of the restaurant, I regularly observed interactions between managers and kitchen workers. After obtaining permission to conduct research from the restaurant's highest-ranking manager, I began collecting examples of Anglo Spanish. The initial motivation for this research was to examine the grammatical structure of Spanish-English alternations in the speech of Anglo workers and managers. It became clear, however, that the ethnographic aspects of Anglo Spanish were much more interesting than their linguistic structure, and I began collecting ethnographic notes in addition to recording instances of Anglo Spanish.

I transcribed written notices in the restaurant, and transcribed and collected tickets for food orders. Because of the difficulties of using recording equipment in a restaurant setting and the brief, fleeting nature of many of the interactions, I recorded verbal directives and ethnographic notes by hand. Employees were expected to carry a notepad and pen at all times, so it was usually possible to transcribe interactions as they occurred or immediately after. Other workers were aware that I was conducting research, and other Anglo workers would sometimes tease me for taking notes or ask me not to write down something that they had said. This article examines these interactions in terms of the ethnography of speaking. The analysis is inherently both subjective and local. Although I take a close look at interactions in a single restaurant, my experiences in other restaurants and discussions with workers from a variety of other restaurants outside Texas suggest that the sort of interactions found at Chalupatown are not unique. The choice to focus on data where issues of language and race are particularly salient ignores the majority of intraethnic interactions in the restaurant. Because of the focus on data involving issues of race, a number of the examples may be highly offensive.

The kitchen workers were evenly divided between workers originally from Guatemala and immigrants from Mexico. Because I had regular contact with the kitchen workers and was able to communicate with them in Spanish, I became close friends with a number of them (for which I was frequently ridiculed by Anglo co-workers). My position in the restaurant was unique in that I was an "in-group" participant in social networks of both servers and kitchen workers. I was, however, simultaneously "out-group" for both groups of workers. My friendships with Spanish-speaking employees made me an outsider for some Anglo 
TABLE 1. Kitchen staff at Chalupatown (order reflects relative status).

\begin{tabular}{|c|c|c|}
\hline Job Title & Primary Responsibilities & Approximate Number \\
\hline line cooks & $\begin{array}{l}\text { preparing food as it is ordered, cleaning line } \\
\text { kitchen }\end{array}$ & 14 ( 1 female, 2 bilinguals) \\
\hline prep cooks & $\begin{array}{l}\text { preparing food for line, making salsa, tamales and } \\
\text { other items that are prepared in advance, cleaning } \\
\text { prep kitchen }\end{array}$ & 8 (all male, 1 bilingual) \\
\hline tortilla makers & $\begin{array}{l}\text { making tortillas and heating tortillas as they are } \\
\text { ordered }\end{array}$ & 3 (all female) \\
\hline busers & $\begin{array}{l}\text { clearing tables, cleaning seating area and } \\
\text { restrooms, maintaining salsa bar and drink } \\
\text { stations }\end{array}$ & 12 (all male) \\
\hline dishwashers & $\begin{array}{l}\text { washing and stocking dishes, unloading and } \\
\text { stocking food deliveries, squeezing orange juice } \\
\text { by hand, occasional work with prep cooks }\end{array}$ & 8 (all male) \\
\hline
\end{tabular}

workers, who would tease me for knowing the names of songs played in the kitchen, for spending time on the "wrong side" of town, and for socializing with Spanish speakers outside of work. As an Anglo I was also an outsider among the Latino kitchen workers, who joked about my ethnic status. Because of my outsider status in the kitchen, workers frequently asked me for favors that would require English or familiarity with American bureaucracy, such as obtaining identification cards, opening bank accounts, or making calls to help in searching for apartments.

During this research, the restaurant maintained around 105 employees, including about 45 kitchen workers and about 45 wait staff workers, with 10 managers. The numbers fluctuated continually owing to a very high employee turnover rate (common in restaurant work). The turnover was so frequent that most of the employees worked in the restaurant for only a few months or even less. All the kitchen workers were Spanish-speaking or bilingual first-generation immigrants from Mexico or Guatemala. The wait staff was overwhelmingly Anglo. The number of first-generation Mexican servers ranged from zero to two, while the number of monolingual English-speaking Mexican American servers never rose above five. Managers were also predominantly Anglo. During the first two years of this research, there were two Mexican American (bilingual) managers, although both no longer worked in the restaurant during the third year. Tables 1 and 2 show the approximate breakdown of kitchen and wait staff at Chalupatown. ${ }^{3}$

In both wait staff and kitchen staff, employees in lower-paying positions have the opportunity to be promoted. Hosts may become servers and servers may become managers. Dishwashers may be promoted to busers and busers may be promoted to prep cooks, who in turn may be promoted to line cooks. Because 
TABLE 2. Wait staff at Chalupatown (order reflects relative status).

\begin{tabular}{|c|c|c|}
\hline Job Title & Primary Responsibilities & Approximate Number ${ }^{\mathrm{a}}$ \\
\hline manager & $\begin{array}{l}\text { overseeing daily operation, scheduling, inventory, } \\
\text { and sales reports; checking server and bartender } \\
\text { daily reports and making alterations to server tickets } \\
\text { (voids, discounts, etc) }\end{array}$ & 10 (4 male, 3 bilingual) \\
\hline server & $\begin{array}{l}\text { serving customers, making tea and coffee, } \\
\text { conducting side work (filling salt shakers, sweeping, } \\
\text { etc) }\end{array}$ & 30 (14 male, 2 bilingual) \\
\hline bartender & $\begin{array}{l}\text { serving customers, filling drink orders, stocking and } \\
\text { cleaning bar area }\end{array}$ & 9 (2 female, 1 bilingual) \\
\hline host & $\begin{array}{l}\text { seating customers, maintaining waitlist, side work } \\
\text { (cleaning menus, etc) }\end{array}$ & $6(2$ male $)$ \\
\hline
\end{tabular}

\footnotetext{
${ }^{a}$ The numbers are approximate due to regular fluctuations resulting from employee turnover.
}

more senior employees in higher positions had experience with other jobs in the restaurants, they were frequently used as a resource for newer employees. However, because managers were promoted from the wait staff (but never from kitchen staff), several Anglo managers were not entirely familiar with the regular work responsibilities of members of the kitchen staff. This lack of knowledge often contributed to problems that arose in interactions between kitchen workers and managers, particularly in cases where the manager was not sure of the usual procedure for completing a particular task.

Despite the relatively even numbers of kitchen and wait staff employees, differences in work responsibilities resulted in an uneven distribution between the two groups during the actual course of the workday. Table 3 shows the approximate number of employees in each job during the course of an average weekday.

Prep cooks and dishwashers were required in the morning before the restaurant had actually opened, and line cooks, busers and dishwashers were needed after it had closed. In contrast, the majority of the wait staff worked only during the heavy business hours of lunch and dinner. Because of the different times required for performing different tasks, the presence of Spanish-speaking versus English-speaking employees fluctuated over the course of a day. Table 4 collapses the various job categories in Table 3 in order to highlight the fluctuations in the Spanish : English ratio.

During the lunch and dinner periods, English-speaking employees slightly outnumbered Spanish-speaking employees. At other times, the workplace was predominantly Spanish-speaking. Interactions varied throughout the day as well. The highest rate of verbal directives between managers and Spanish-speaking employees occurred during the morning hours. During the hours before the lunch rush, Spanish-speaking employees were responsible for a more diverse set of 
TABLE 3. Number of workers in each position over the course of a day.

\begin{tabular}{|c|c|c|c|c|c|c|c|c|c|}
\hline \multirow[b]{2}{*}{ Time } & \multicolumn{4}{|c|}{ Primarily English-Speaking Employees } & \multicolumn{5}{|c|}{ Primarily Spanish-Speaking Employees } \\
\hline & manager & host & bar & server & line & bus & dish & prep & tortilla \\
\hline $6-9 \mathrm{am}$ & 1 & & 1 & & 2 & & 2 & 3 & 1 \\
\hline 10am & 2 & & 1 & 2 & 4 & 1 & 2 & 4 & 1 \\
\hline $11 \mathrm{am}$ & 2 & 1 & 1 & 4 & 5 & 3 & 2 & 4 & 1 \\
\hline $12 \mathrm{pm}$ & 2 & 3 & 1 & 11 & 5 & 4 & 2 & 3 & 1 \\
\hline $1 \mathrm{pm}$ & 2 & 3 & 1 & 11 & 5 & 4 & 2 & 3 & 1 \\
\hline $2-4 \mathrm{pm}$ & 2 & 1 & 2 & 3 & 5 & 4 & 2 & 3 & 1 \\
\hline $5 \mathrm{pm}$ & 2 & 3 & 2 & 7 & 6 & 5 & 2 & & 2 \\
\hline $6 \mathrm{pm}$ & 2 & 3 & 3 & 14 & 8 & 5 & 3 & & 2 \\
\hline 7-9pm & 2 & 3 & 3 & 14 & 8 & 5 & 3 & & 2 \\
\hline $10 \mathrm{pm}$ & 2 & 2 & 2 & 7 & 8 & 5 & 3 & & 1 \\
\hline $11 \mathrm{pm}$ & 2 & & 2 & 5 & 6 & 5 & 3 & & \\
\hline $12 \mathrm{am}$ & 2 & & 1 & 2 & 4 & 5 & 3 & & \\
\hline
\end{tabular}

TABLE 4. Number of employees speaking each language over the course of a workday.

\begin{tabular}{lcc}
\hline \hline Time & Spanish & English \\
\hline $6-9 \mathrm{am}$ & 8 & 2 \\
$10 \mathrm{am}$ & 12 & 5 \\
$11 \mathrm{am}$ & 15 & 8 \\
$12 \mathrm{pm}$ & 15 & 17 \\
$1 \mathrm{pm}$ & 15 & 17 \\
$2-4 \mathrm{pm}$ & 15 & 8 \\
$5 \mathrm{pm}$ & 15 & 14 \\
$6 \mathrm{pm}$ & 18 & 22 \\
$7-9 \mathrm{pm}$ & 18 & 22 \\
$10 \mathrm{pm}$ & 17 & 13 \\
$11 \mathrm{pm}$ & 14 & 9 \\
$12 \mathrm{am}$ & 12 & 5 \\
\hline \hline
\end{tabular}

tasks, such as cleaning the restaurant, squeezing orange juice, making masa (dough) for tortillas, checking inventory, receiving deliveries, slicing meats and vegetables, and cooking large quantities of beans and rice. Because these tasks were often shuffled back and forth to accommodate specific needs (such as the arrival of deliveries), morning managers needed to use frequent verbal directives to ensure that each of these diverse tasks would be completed. During the 
lunch and dinner rushes, the primary form of directives was food orders sent to the kitchen by a computerized ordering system. Verbal directives certainly occurred during these periods, but they were restricted primarily to solving specific problems (incorrect orders, running out of a particular food item, etc). Thus, the majority of verbal directives in this study occurred during the hours before the restaurant officially opened; while the food orders obviously occurred during working hours.

\section{Racism at Chalupatown}

Despite the fact that the entire enterprise of Chalupatown was centered around Mexican culture and cuisine, racism (particularly toward Latinos) was fairly common among a relatively small subset of the restaurant's wait staff. Some (though definitely not the majority) of the Anglo servers regularly exchanged strongly racist evaluations of their customers. These evaluations often included open use of offensive racist pejoratives. For example, one server complained to another that he was not receiving good tips because he had been repeatedly given "bad tables" by the host. Because of an ongoing dispute between the two, the server felt that the host was intentionally seating minority customers in his section to prevent him from making good tips. He complained to another server, "You would not believe the tables I've had today - Look, I made a list: four tables of beaners, two tables of niggers and one table of deaf-mutes." My reaction to overhearing this resulted in an apology for using offensive language followed by several days in which various servers made repeated jokes and negative comments about my "hypersensitivity." The fact that such racist banter was tolerated by some of the servers and managers reflects the lack of concern about racism among the Chalupatown staff.

For these particular servers, keeping track of the ethnic background of their customers was viewed as a valid way to gain a sense of how much tip money they were making, with the implicit assumption that the more white customers one had, the higher his or her tips would be. Because their racist attitudes influenced the service they provided minority customers, their expectations of small tips were usually fulfilled. This group of Anglo servers regularly complained when given a table of Latino customers and consciously provided Latino customers with inferior service because of the racist assumption that Latino customers don't tip well. When the inferior service resulted in a small tip, this was seen as justification for inferior treatment itself, rather than as the actual result of providing poor service. Given that the customers were overwhelmingly Anglo, these servers felt they could afford to let service to Latino customers slide and make up the income by focusing on Anglo customers.

One server ultimately realized that she - not the race of her customers - was the cause of the low tips, and that her racist attitude was not in her own interest. She and I were scheduled to work the same shift as servers in adjacent sections of the restaurant. She arrived late, so I was given a table in her section. When she 
arrived, I apologized for taking her table and offered to have the manager transfer the ticket so that she could be their server. When she saw that the table was filled with a large Latino family, she said, "No way. You can have them. In fact, I'm giving you all my beaners today." Throughout the day she told the hosts to seat Latino customers in my section rather than hers, assuming she would increase her tips by giving me the "low-tipping" Latino customers and keeping the "high-tipping" Anglo customers for herself. At the end of the day the amount of my tips was substantially higher than what she had earned. She had a reputation as one of the highest-earning waitresses in the restaurant, and having been "outtipped" was something of an embarrassment for her, especially since she had told several other servers that she was sabotaging my tips. A couple of weeks later, she thanked me for showing her that she had been wrong, saying, "If you're nice to them, they tip you really well. Now I just pretend not to hate them."

There were also occasional expressions of racist attitudes by some of the managerial staff, although these were much less common and less likely to be expressed openly, and they rarely included the use of pejoratives. One manager frequently had parties at her house that were initially open to the entire restaurant staff, although they were primarily attended by servers and other managers. The first time I attended one of the parties, I happened to bring several Spanishspeaking co-workers. From this point on, the parties stopped being open to all employees and became "invitation-only." After realizing that I knew the parties were continuing, the manager apologized for not inviting me, saying that it was because I regularly socialized with Spanish-speaking co-workers and she "didn't feel comfortable having them in her house." I was told that I was actually welcome at her parties in the future as long as I agreed not to bring any of the kitchen workers with me. The racialized nature of managerial attitudes toward the workers is reflected in the following interaction, which occurred when I came to pick up my paycheck.

(2) Manager: Oh, your check isn't in this pile, this is the brown pile?

Me: They're divided that way?

Manager: Well, you know, kitchen and wait staff.

Rather than refer to the kitchen staff in terms of the division of labor (the actual reason for two sets of checks), the manager referred to the stack of kitchen checks as the "brown pile." This incident is typical of the way in which the kitchen staff was viewed as a racialized Other by much of the Anglo staff. Managers and servers frequently referred to kitchen employees with phrases such as "that one" or "those two" rather than with personal pronouns such as "him" or "them." Many servers did not even seem to know the names of Spanishspeaking employees, and they would regularly ask bilinguals for the names of cooks and busers they were working with. Often, the question would be phrased as "What's that one there called?" rather than "What's his name?" or "What's that guy's name?" The use of "that one" dehumanizes the referent, similar to 
the use of animal metaphors in public discourse about Latinos discussed by Santa Ana 1999, 2002.

Racist assumptions were common among the restaurant's customers as well. One Chicano server (a native English speaker) repeatedly found that customers were hesitant to interact with him directly. Occasionally clients would express doubt that he was their actual server (despite his having introduced himself as such) and repeat their requests to an Anglo co-worker, explaining that they weren't sure that he was actually their "waiter." After repeatedly being taken for a buser rather than a server, he quit his job at Chalupatown (less than a month after starting) to take a job in another restaurant with more Latino servers and customers.

Despite the prevalence of such attitudes, neither the servers nor managers ever expressed the view that the restaurant was a "racist" environment. The owners often provided helpful services to Spanish-speaking workers, such as offering interest-free loans to longtime employees and helping with legal and medical matters. In organizing work-related events, the managerial staff always tried to convey a sense of inclusiveness, posting notices of events such as holiday parties or company picnics in both English and Spanish. Because they offered employee services that were absent in most restaurants, the treatment of Spanish-speaking workers at Chalupatown was in many ways much better than in other Anglo-owned restaurants. For the most part, the managerial staff (including the owners) saw themselves as open-minded and accepting toward Latino employees and did not feel that white racism was a problem in their establishment. If the owners did hear racist comments from Anglo workers, they were usually quick to chastise them. There was no overt attempt at discrimination, and racism was not discussed at meetings between workers and management. If racism was an issue, it was usually expressed in terms of Latino workers' attitudes toward whites. The segregated nature of the staff (with almost entirely Anglo wait staff and entirely Latino kitchen staff) was explained as being necessary and efficient, because the Latino workers were uncooperative and unwilling to work closely with English-speaking whites. This type of projection is typical in the discourse of color-blind racism (Bonilla-Silva \& Forman 2000, Bonilla-Silva 2002), in which racist ideologies are reproduced in discourse that is outwardly anti-racist.

\section{ANGLO USE OF SPANISH AT CHALUPATOWN}

The menu at Chalupatown included a number of Mock Spanish phrases, such as "not your ordinario hard-shell tacos," "blended with fruita fresca" (cf. Spanish fruta 'fruit') and "big enough for a macho man!" 4 The menu even featured the gratuitous use of inverted exclamation marks on English phrases, as in "iYou'll love it!" The use of Mock Spanish at Chalupatown extended well beyond the menu, however. In many of the interactions at Chalupatown, Anglo speakers 
used Mock Spanish when communicating with Spanish-speaking employees. Although some Anglos simply issued directives in English, many used Spanish words embedded into otherwise English sentences, as in "You need a sharper cuchillo" ('knife').

At Chalupatown, ways of using Spanish were iconic markers of ethnic identity, with the use of Mock Spanish indexing a particular Anglo identity and the use of actual Spanish indexing Latino identity. It was common to comment on deviations from this racialized view of Spanish, and the ethnic authenticity of bilinguals was openly questioned by both Latinos and Anglos. One kitchen worker who had gained fluency in English was often singled out as "one of us" - "acceptable" to spend time with outside of work (e.g., being invited to parties held by servers). Similarly, I was told that I was a "burrito" (explained to me as being "white on the outside but pure beaner on the inside") for maintaining close friendships with Spanish-speaking co-workers.

The iconicity (Gal \& Irvine 2000) of Spanish as an index of Latino identity is certainly not unique to Chalupatown (cf. Urciuoli 1996:35-37). Despite the fact that there were more Anglos able to speak Spanish than Latinos able to speak English, the communicative burden was implicitly a unidirectional accommodation to English. When I began working in the restaurant, I was told that I was "lucky" to speak Spanish because "they can't talk to us." The inverse ("we can't talk to them") was never expressed.

Although Anglos generally ignored conversations in Spanish, they regularly expressed suspicion about Spanish speakers that were directed to Anglo listeners, and exchanges between Spanish speakers were often interpreted as intentionally secretive (cf. Haviland 2003). It was commonly assumed that Spanish speakers were either saying something bad about a white co-worker, were doing something "under the table," or were giving one another preferential treatment. This suspicion moved beyond language use, so that kitchen employees were often suspected as being responsible for unexplained problems in the restaurant, such as missing food and liquor or a rise in food costs. ${ }^{5}$ During a widely discussed attempt to reduce rising food costs, a handwritten sign was posted reminding servers that they were not allowed to take anything from the kitchen unless it had already been entered in the computer and a ticket had been printed:

(3) The kitchen cannot fill an order without a ticket. No exceptions - EVEN IF YOU SPEAK SPANISH!!

The phrase even if you speak Spanish!! was underlined three times and highlighted in yellow in addition to being written in all capital letters. Although there were only two native Spanish-speaking servers employed in the restaurant at the time, the manager writing the sign made language a specific issue as if to suggest (wrongly) that the problem with food costs was largely caused by the kitchen staff's showing favoritism toward other Spanish-speaking workers by allowing them to take food without placing an order for it. 
Suspicion about interactions in Spanish and asking for names were the only contexts in which Anglo servers consistently sought out the help of bilingual employees. This generally occurred when servers were concerned that they were the subject of Spanish conversations and may have been insulted or sexually harassed. English speakers frequently sought help from a bilingual in order to learn a derogatory phrase that could be used as a retort. English-speaking coworkers often asked me how to say things like "Fuck off!" or "I'm gonna cut your dick off!" (I was, however, never asked how to say something like "How was your day off?") This is similar to Flouton's (1991) description of teaching a Spanish course for restaurant managers in New York: she found that the students were more interested in learning Spanish for confrontations with co-workers than in the materials she had prepared based on "useful" vocabulary for restaurant work. Flouton (1991:195) writes that "most students were usually looking for the definite word or expression to put Hispanics in their place so as not to be constantly the victim of derogatory remarks on their part." At Chalupatown, the use of bilinguals to facilitate confrontational language and translate obscenities was not restricted to potential cases of supposed "victimization" in Spanish. Although bilinguals were rarely used to translate directives that arose in the regular course of work, they were frequently sought for help in making reprimands and overt expressions of anger. For example, one manager who was firing an employee instructed a bilingual, "Tell him to get the fuck out of my restaurant and to never come back and I want you to translate it just like that!"

\section{The structure of Spanish-English alternation in Anglo speech}

As noted above, my initial motivation for collecting data was to study the grammatical structure of Anglo code-switching at Chalupatown. The structure of alternations in Anglo speech is distinctly different from that of those found in studies of codeswitching by native Spanish-English bilinguals. In a groundbreaking study of Spanish-English codeswitching among Puerto Rican speakers in New York, Poplack 1981 proposed two constraints that govern how two languages can be combined:

Free morpheme constraint: codes may be switched after any constituent in discourse provided that constituent is not a bound morpheme.

...

Equivalence constraint: code-switches will tend to occur at points in discourse where juxtaposition of L1 and L2 elements does not violate a syntactic rule of either language. (Poplack 1981)

Poplack illustrates the free morpheme constraint with the example *eat-iendo 'eating', where the Spanish suffix -iendo is a bound morpheme. The equivalence constraint would be violated by switches such as "a car nuevo" (Poplack 1981; cf. Gingràs 1974). Here the syntax of Spanish un carro nuevo and English a new car differ in that the adjective in English is before (rather than after) the 
noun. Both of these constraints were regularly violated in Anglo code-switching, as in the examples below:

(4) Thank you for trabajo-ing. (trabajo 'work', 1st person singular or noun) Violates the bound morpheme constraint.

(5) Did you put bolsas in your basura cans? (bolsas 'bags', basura 'garbage') Violates equivalence (cf. Spanish botes de basura 'garbage bags').

Spanish-English bilinguals may violate these constraints as well, but codeswitching of these types is rare. In Poplack's original study, violations of the equivalence constraint were found in less than $1 \%$ of all switches (Poplack 1981). Although Poplack found no violations of the bound morpheme constraint, MyersScotton (1993:34) notes that the bound morpheme constraint may be violated (as in boil-ando 'boiling') by Spanish-English bilinguals in Texas. Given the rarity of such examples in studies of code-switching, it seems reasonable to assume that such violations are atypical of code-switching by native bilinguals. In recording examples of Anglo use of Spanish, I originally hoped to find interesting data that might demonstrate how these constraints were violated by Englishdominant speakers. It quickly became clear, however, that the violation of these constraints in Anglo uses of Spanish was not a question of code-switching patterns, but simply the result of a total absence of Spanish grammatical structure in Anglo speech (despite the presence of Spanish morphemes).

Although Anglo managers and servers might occasionally produce directives entirely in Spanish, directives were more typically given either entirely in English or in a mix of English and Spanish. Most use of Spanish by Anglos in the restaurant involved the substitution of single Spanish morphemes into otherwise English sentences, as in the following examples:

(6) There's agua ['water'] on the piso ['floor'].

(7) Did you limpia the baño?

(limpia 'clean' 3rd singular present or adjective; baño 'bathroom')

(8) Why is this still sucio ['dirty']?

(9) Can you ayuda with these boxes?

(ayuda 'help' 3rd singular present or noun)

Although Anglo speakers used Spanish often, the syntactic structure of these utterances was consistently English. The syntactic structure of Spanish was never involved. Anglo use of Spanish almost always involved cases of "nonce loans" (Poplack et al. 1988) or "insertions" (Muysken 2000) of Spanish constituents into English sentences.

The absence of Spanish grammatical structure in Anglo code-switching might lead one to assume that these utterances result from a lack of competence in Spanish. While it is clear that many of the Anglo speakers were not fluent speakers of Spanish, most of them had enough competence to produce many of these directives in Spanish. In cases of extreme urgency, Anglo speakers would often 
use sentences that were entirely in Spanish. The use of actual Spanish by Anglos was most common when in emergency situations or as a last resort when miscommunication had become an obvious problem. The following interaction took place after a prep cook cut his hand on the meat slicer. The manager is opening the first aid kit to pull out a bandage while another employee brings a car around to take the cook to the emergency clinic. Following the manager's instructions, the cook is holding his hand above his shoulder in a towel. The cook had lowered his hand several times and the manager repeatedly asked him to keep his hand up (a pattern that continued after this interaction):

(10) Manager (to cook): Hay que dejar la mano arriba.

(cook lowers hand again)

'You have to keep your hand up.'

Manager:

¡Hay que dejar la mano arriba!

'You have to keep your hand up!'

Manager (to Rusty):

Rusty:

Tell him he needs to keep his hand up

Dice que -

'She says that -'

Cook:

- OK, OK (lifts arm)

Here the manager uses Spanish syntactic constructions that are quite distinct from English grammar. The construction hay que 'it is necessary that' has a null subject where English would generally use a personal pronoun. If the manager had been using only English grammar one might expect something like tu necesitas 'you need to' rather than an impersonal construction like hay que. The manager also correctly uses the definite article la with the noun mano (hand) where English would use a possessive pronoun (your hand). The correct use of the feminine la rather than the masculine $e l$ with the noun mano avoids another pitfall of L2 Spanish speakers, who may mistakenly use the masculine article under the assumption that all nouns ending in [o] have masculine gender. The (incorrect) use of $s u$ mano is extremely common in Anglo Spanish; even the restrooms at Chalupatown had the typical Mock Spanish Lava sus manos sign found throughout the Southwest (Peñalosa 1981, Hill 1998). The manager was at least fluent enough in Spanish to produce syntactic constructions that often pose difficulties for English monolinguals using Spanish as a second language. When the cook returned to work the next day, the same manager asked him "How is your mano?" - returning to the nonce borrowing pattern typical of Anglo Spanish. Although a lack of competence might explain some examples of Anglo nonce borrowings, in many cases the absence of Spanish grammar does not result from a lack of fluency, but rather reflects the absence of any attempt actually to speak Spanish.

The absence of Spanish syntax in Anglo speech at Chalupatown is similar to other forms of linguistic appropriation, which typically involve a greatly reduced (or entirely absent) grammatical structure of the source language. Actual Spanish grammar is virtually nonexistent in Mock Spanish, where the only productive grammatical processes seem to be the addition of $+o$ to English nouns and the addition of the article $\mathrm{el}$. Of course, the affixation of $+\mathrm{o}$ is not actually a 
rule for Spanish (actual Spanish nouns end in a wide range of sounds). Instead, the rule is specific to Mock Spanish. In an examination of Spanish textbooks written for Anglo employers, Erard 1996 also found that Spanish grammar is often greatly reduced or ignored in Anglo speech. For example, the authors of Farm and Ranch Spanish choose only to introduce the formal personal pronoun Usted, ignoring the familiar pronoun tú and its associated verb forms (Erard 1996:314), erasing the potential for indexing a position of familiarity with Spanish speakers. The general irrelevance of Spanish grammar for Anglo speakers reflects an ideology in which Spanish speakers themselves are viewed as inconsequential (cf. Santa Ana 2002:2-3). The erasure (Gal \& Irvine 2000) of Spanish syntactic structure reflects a racial ideology involving erasure of Latinos themselves (cf. Perea 1995).

Anglo Spanish serves as an example of what Zentella 1996 has called the process of "chiquitification" of Spanish and Spanish speakers. Zentella defines "chiquitification" as a process which "diminishes the complexity of the languages and cultures of the more than 22 million Latinos who reside in the U.S." (1996:1). She argues that the ideology of chiquitification fuels discrimination and Hispanophobia. The difficulties Spanish-speakers at Chalupatown face when confronted with a chiquitified Spanish demonstrate the powerful impact of chiquitification in the everyday lives of Spanish-speakers.

\section{Anglo Spanish as Mock Spanish}

That Anglo use of Spanish is often simply Mock Spanish is evident in the exchange between a server and a bartender in example (11) below. The interaction occurs in a wait station, a small room with doorways on three sides that connects the kitchen, bar, and serving area. The area is only about four feet across, so that it is possible to conduct conversations across the room (such as between the bar and the kitchen). Because the area contains many items essential to servers (chips, soda machines, tea and coffee, an ice bin and a register), the wait station is continuously busy with numerous workers passing back and forth between parts of the workplace. The server is standing in the wait station filling glasses at the soda machine as the bartender is returning from the restroom. As the bartender passes through the wait station to the bar, the server stops and asks him to have the buser refill the ice bin.

(11) Server: Will you ask $\langle$ Luis $\rangle$ to refill the ice bin?

Bartender: OK... How do you say "ice"?

Server: I don't know? Ice-o? (both laugh)

Bartender (to buser who is passing through the wait station): Mas ice-o, por favor.

Buser: ¿Qué?

'What?'

[The server and bartender both laugh. The buser turns to Rusty, tilts back his head, and turns his hands up to indicate that he wants an explanation.]

Rusty: (to buser) No quiere nada.

'He doesn't want anything.'

[Buser exists the wait station.] 


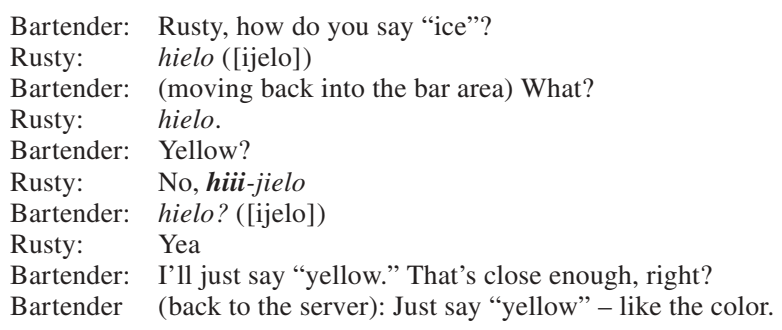

Example (11) reflects the common practice among Anglo servers of avoiding directives to Spanish employees by passing them off to other employees, particularly those who are newer, younger, or lower-status (i.e., not necessarily based on their potential competence in Spanish). In this example, the server's choice to pass the directive off to the bartender may result from the face-threatening nature of this specific request. Refilling the ice bin is not the buser's responsibility, and the server is basically trying to trick the bartender into convincing the buser to perform what should be the server's own job responsibility (hence my response to the buser). As a fairly new employee, the bartender was unaware that the job was the server's responsibility and became angry when I explained the situation later.

In this example, the speakers immediately resort to Mock Spanish when discussing how to communicate to a Spanish speaker. The first example, mas ice-o, involves the use of Spanish grammatical elements on English words (the addition of $+o$ to an English noun). Immediately upon learning (and correctly pronouncing) the Spanish word, the bartender turns to hyperanglicization ( yellow). Although the other bartender asks me if yellow is close enough to be understood as hielo, he instructs the server to just say yellow before I have a chance to respond. The Mock Spanish nonce forms are quite funny to the speakers, and both the server and bartender laugh throughout and after the exchange. Here the Spanish does not serve to facilitate communication with the Spanish-speaking employee; it does little more than index the racial difference between the buser and the servers themselves. The Spanish is entirely for the benefit of the Anglo speakers' own amusement, and the actual Spanish speaker is quite marginal to the interaction despite the fact that it revolves around an attempt to communicate with him. Spanish simply serves to index a particular Anglo understanding of social affect and humor, but it does not actually serve the function of facilitating communication with Spanish speakers (see discussion below).

The widespread use of Spanish obscenities noted earlier is another affinity between Anglo Spanish at Chalupatown and the mass-media productions of Mock Spanish described by Hill. Spanish expletives occurred both as substitutes for English obscenities and in combination with English expletives. Several English male monolinguals frequently boasted about their ability to express obscenities accurately in Spanish. These male servers repeatedly produced Span- 
ish obscenities as an attempt at humor. A few male servers would regularly approach monolingual Spanish-speaking males with no other purpose than to utter highly offensive Spanish words in isolation. One server in particular would persistently accost male Spanish-speaking employees and yell isolated Spanish obscenities referring to female anatomy. These outbursts were usually prompted by the presence of a female customer he found attractive somewhere in the restaurant. However, the woman in question was rarely (if ever) near enough to be recognized as a contextual factor, so his outbursts seemed to occur for no reason at all. The Spanish speakers would occasionally react with laughter, but more often simply roll their eyes or shake their heads. Among other Anglos, the word caca 'shit' was the most common Spanish obscenity. Managers would regularly used caca in directives such as "Why is there caca on the floor?" (referring to trash that has spilled). Thus, common uses of Spanish at Chalupatown reflected stereotypical forms of Mock Spanish both in terms of their English-centered structure and in their negative indexical associations.

\section{Use of directives at Chalupatown}

Verbal directives. The Anglo managers at Chalupatown had distinct individual responses to the problem of communicating with Spanish-speaking employees, depending on individual stances toward Latino co-workers. Two of the Anglo managers knew enough Spanish to produce directives that were understandable in Spanish. Both these managers recognized that racism was a problem in the restaurant, something most other managers denied. In sharp contrast, two managers who openly expressed racist attitudes both used only English in interactions with Spanish speakers, with the exception of a few select Spanish words that were common knowledge among all employees (e.g., mesa, agua, queso). Regardless of whether they were speaking English or Spanish, Anglo speakers would often produce the English items with exaggerated nonnative phonology (e.g. [t乏íikin] or [t乏iips]) but produced anglicized forms of the Spanish items (e.g. [ $\mathrm{k}^{\mathrm{h}}$ éjsow] for queso). Spanish speakers used unmodified Spanish phonology for both the English and Spanish words.

The managers using "pure" English typically produced directives containing elements of "foreigner talk" (Ferguson 1975, 1981). Foreigner talk is a register that speakers use in attempts to communicate when they assume that an interlocutor does not know the speaker's language. Features of foreigner talk used by Anglo workers at Chalupatown included exaggerated gestures and facial expressions, speaking at higher amplitude, exaggerated pronunciation, and syntactic reduction. Frequently, Anglo speakers would use an exaggerated Mock Spanish accent when communicating with Spanish-speaking co-workers - for example, the phrase "MORE CHIPS" with the second word produced [t $\mathrm{E}$ iips], accompanied by the gesture of pointing at the empty chip container. As with the use of 
Mock Spanish, the use of exaggerated nonnative pronunciation reproduced a negative racial stereotype for Anglo amusement.

The effectiveness of these directives was limited to a few specific contexts. Only one of the managers regularly sought out bilingual workers to translate directives to the kitchen staff. It is probably not coincidental that this particular manager grew up in Europe, was a native trilingual, and had a very positive attitude toward multilingualism.

The predominant means of issuing directives was used by managers with some knowledge of Spanish and involved utterances with primarily English content, with occasional words and (more rarely) phrases in Spanish. The amount of Spanish content varied, but it was sometimes insufficient for conveying meaning to a monolingual Spanish speaker. The phonology of these switches was always hyperanglicized, as in [hæbla.I] for hablar and [tclejfownow] for telefono in the following example:

(12) Manager: Could you hablar 〈Juan〉 por telefono and see if he can trabajo? hablar 'to speak'; por telefono 'by phone'; trabajo 'work' (1st person singular present or noun) 'Could you talk (to) Juan by telephone and see if he can work?'

Although directives of this type were quite frequent, the managers seemed to recognize that they were often unintelligible to monolingual Spanish speakers. In the following example, the manager openly admits that the directive was not understood:

(13) Manager: Did you go psst psst with the manguera ['hose'?

Employee: Sí, sí. ['Yes, yes']

Manager: Did you put bolsas ['bags'] in your basura ['garbage'] cans?

Employee: Sí, sí.

Manager: (to Rusty, working nearby): He didn't understand a thing I said. It takes them a while to get used to that. The scary thing is eventually they start to know what I'm saying.

It is assumed that Spanish-speaking employees will eventually "get used to" receiving directives that they cannot understand. Despite recognizing that directives were not always understood, managers typically blamed failure to follow a given directive on the Spanish-speaking employee. In the following example, a manager blames the failure on the "laziness" of the Spanish-speaking employee rather than on miscommunication, despite the fact that the directive contained only three words in Spanish, none of which is particularly helpful for determining the meaning of the sentence:

(14) Manager: You have to finish todo eso, porque I have other things to do. todo eso, all this; porque because

Manager (later to Anglo employee): Did you see that? He didn't finish that - he didn't do what I told him!

Rusty: Maybe he didn't understand you.

Manager: Oh, he understood me all right, he's just lazy. 
Having been told only 'all this' and 'because' in Spanish, the employee was left without sufficient information to comprehend the directive; it could be equally interpreted as 'I'll finish all of this because you have other things to do'. Nonetheless, when the directive was not followed, the manager accused the employee of being lazy.

These verbal directives maintain their performative effect as directives. Spanish speakers recognize that they are expected to perform some task. However, the referential function of the directives often fails because of the limited Spanish content. Spanish speakers are thus left in a situation where they must complete directives they may not fully understand (see below). The actions of Spanish speakers are evaluated as if the failure to fulfill directives were a willful act rather than a failure to understand. The linguistic form of these directives restricts the agency of Spanish speakers by limiting the effect their actions may have both on themselves and on others. Spanish speakers are often left with insufficient information for performing their job successfully but are still subject to managerial evaluation of their actions.

Written notices for employees. Written notices posted for employees were much more likely to be entirely in Spanish, as opposed to the predominantly English verbal directives. The notices were sometimes written out by hand but more often prepared using a computer. Translations were either written out by managers themselves (often after consulting a bilingual) or obtained by using machine translation programs available over the Internet. Bilinguals were more likely to be consulted in the production of written notices than in the case of verbal directives. In cases where a bilingual was used, the translation was often orally transmitted, resulting in numerous changes when it was written down by the monolingual English speaker. The written notices typically contained sufficient Spanish for comprehension but displayed very little regard for actual Spanish grammar. For example, the written notice below (a reminder about daylight savings time) contains a mix of accurate and ungrammatical language:

(15) recuerden cambiar la hora a su relog el sabado en la noche cuando sean las 12:00 pm seran las 11:00pm 'remember to change the hour on your clock Saturday night when it is 12:00 pm, it will be 11:00pm'

In this case, the manager consulted with a bilingual speaker before printing out the final version of the notice. These consultations were cursory, usually just intended to check for the comprehensibility of particular words or phrases. Thus, the final version of the notice contains several errors despite the input of a native speaker (e.g. a su relog for del reloj, en la noche for por la noche). Notices prepared in consultation with bilinguals often contained grammatical forms not typically used by the managers themselves. For example, the notice about time change contains a fairly sophisticated use of the subjunctive and future tenses 
(cuando sean las 12:00 pm seran las 11:00pm) that would not normally occur in the spoken Spanish of any of the Anglo managers.

The only time I was asked to check a translation, I was explicitly told not to worry about whether the grammar and spelling were correct, but only to verify that the notice would be understandable to a monolingual Spanish speaker. I was told that the use of "correct" Spanish was unnecessary because "most of them can't read anyway." This explanation surfaced repeatedly both as a justification for disregarding the grammatical rules of Spanish and as an explanation for misunderstandings in the transmission of kitchen orders (see below).

The managers and owners regularly (and incorrectly) asserted that the majority of the kitchen staff was illiterate. Although it would make sense to assume that a person with supposedly limited literacy skills would be more likely to understand written language if it were actually grammatical, the managers assumed that because the workers didn't regularly use formal standard Spanish, it was acceptable to address them in language that was highly nonstandard and irregular. This view persisted despite the fact that employees regularly corrected the ungrammatical Spanish in written notices, as in the example below:

\begin{tabular}{|c|c|c|}
\hline Original Spanish text & $\begin{array}{l}\text { Corrections made } \\
\text { by employees } \\
\text { (underlined in bold) }\end{array}$ & English translation \\
\hline $\begin{array}{l}\text { Junta obligataria para } \\
\text { todas las personas, de la } \\
\text { cosina, la preparacion, los } \\
\text { trastes, tortillas, los que } \\
\text { limpian mesas. Tienen que } \\
\text { venir a una de las juntas } \\
\text { que abra. }\end{array}$ & $\begin{array}{l}\text { Junta obligataria para } \\
\text { todas las personas, de la } \\
\text { cocina, la preparacíon, los } \\
\text { trastes, tortillas, los que } \\
\text { limpian mesas. Tienen que } \\
\text { venir a una de las juntas } \\
\text { que habrá. }\end{array}$ & $\begin{array}{l}\text { Obligatory meeting for all } \\
\text { of the people, of the } \\
\text { kitchen, the preparation, } \\
\text { the dishes, tortillas, those } \\
\text { that clean tables. You(pl) } \\
\text { must come to one of the } \\
\text { meetings that might open } \\
\text { (fixed by employee to } \\
\text { "will occur") }\end{array}$ \\
\hline
\end{tabular}

As posted, the verb in the second sentence of the posting ( $a b r a)$ was written without the initial $\langle\mathrm{h}\rangle$ and without the accent on the final vowel. The written form is the present tense subjunctive of abrir 'to open' rather than the (intended) future form of haber 'to do'. The employee's correction restores the intended semantic content in addition to correcting spelling errors. Although the verb was corrected by a Spanish-speaking worker, this particular nonstandard orthography was actually used by some of the workers themselves. For example, the only notice written by the workers themselves contains exactly the same error:

(17) TODOS ESTAN INVITADOS AL GRAN JUEGO DE FUDBOL QUE SE LLEVARA ACABO EL DIA 4 DE JULIO A LAS 9 DE LA MAÑANA EN EL PARQUE DE 〈NOMBRE〉.
EVERYONE IS INVITED

TO THE BIG SOCCER GAME

THAT WILL TAKE PLACE ON

THE 4TH OF JULY

AT 9 IN THE MORNING

IN 〈NAME) PARK 
JUGARAN LOS CREMAS DE GUATEMALA Y LOS HUELE MOLE DE MEXICO. NO FALTES. ABRA MUCHA CERVEZA Y ANTOJITOS. QUE GANE EL MEJOR.
THE CREAM OF GUATEMALA WILL PLAY THE MOLE [sauce]-SMELLING MEXICANS. DON'T MISS IT. THERE WILL BE A LOT OF BEER AND SNACKS. MAY THE BEST TEAM WIN.

Written notices posted by managers also contained sporadic inclusions of English content words with no regard for whether the employees would know what the English words actually meant, as in the examples below (note also that necesito is spelled incorrectly in the second example despite the fact that the correct spelling is closer to the English cognate "necessary"):

(18) Hay muchos cambios en schedule. 'There are many changes in schedule.'

(19) Nesisito un busboy dishwasher 'I need a busboy dishwasher Domingo Jan 2nd P.M. Sunday Jan 2nd P.M.'

The most striking difference between Spanish and English notices posted at Chalupatown was that English notices were almost always mitigated in some way, while Spanish notices were more direct. Typically, English notices included an explanation for a particular directive, particularly in cases in which the workers might react negatively to the directive itself:

(20) Due to the very "high cost" of avacados, they are no longer available to staff who eat free meals. This includes guacamole. Employees who pay $\frac{1}{2}$ price may continue to have guacamole and avacado.

(21) PLEASE, DO NOT PLACE ANY OBJECTS BEHIND THE REGISTERS. ( . . because there are a lot of electrical wire thingys back there. Don't touch.)

Thank you.

In example (20), the directive against eating avocados is accompanied by a justification (the price of avocados). The quotes around "high cost" seem to mark emphasis. Like the Spanish-speaking employees, English-speaking workers regularly corrected such errors on the notices themselves, often adding negative comments about the management. In example (21), the directive against placing objects behind registers also comes with an explanation. The informal tone of the justification (electrical thingys) and the inclusion of thank you further mitigate the directive. While nonstandard English marks familiarity, nonstandard Spanish serves to maintain social distance.

In contrast, Spanish-language notices were very direct and rarely included justification or explanations; they sometimes went so far as to include threats. An example is a notice that appeared during the "toilet paper war" between management and employees. There were often problems with the plumbing at Chalupatown, particularly in the restrooms. Overflowing toilets were common, especially on weekends when the restaurant was extremely busy. The busers regularly had to deal with these floods by manually unclogging the toilets and cleaning the water and excrement from the bathroom floor. Because the toilet was a continual problem, many of the Spanish-speaking workers put used toilet paper 
on the floor rather than placing it directly in the toilet and contributing to another flood. This follows the practice in most parts of Mexico and Central America, where the plumbing cannot operate properly when paper is flushed down the toilet. Many of the Mexican and Guatemalan workers maintained this practice in their own homes, placing a waste basket beside the toilet to collect paper rather than flushing it. Although the management was aware of this practice, they did not want waste baskets beside the toilets and were upset by customer complaints about piles of used toilet paper on the floor.

The managers first attempted to resolve the problem by selectively directing busers to not leave paper on the floor and asking them to spread the word to other Spanish-speaking employees. When the busers were told to let other employees know to flush their paper, they responded by explaining the problem with the plumbing and asking for the toilet to be fixed in order to accommodate flushed paper. The requests for repairs were ignored, and the verbal directives failed to resolve the problem. The management then posted the following written notice:

(22) Haga usted el favor de tirar el papel santario adentro de la taza de el excusado no en el piso. SU TRABAJO PELIGRA.

'Do the favor of throwing the sanitary paper inside of the bowl of the toilet not on the floor. YOUR JOB IS IN DANGER.'

In addition to the predictable grammatical errors (e.g., de el for $\mathrm{del}$ ), the notice is somewhat overstated. The most direct way to make this directive would be simply to say, "Don't throw toilet paper on the floor" ( "No tire Usted papel higénico al suelo"). The highly explicit and threatening nature of the notice contrasts sharply with the mitigated English notices and reflects the assumption that Spanish-speaking employees have a general problem with comprehending directives and require overly explicit directions accompanied by threats. It also places responsibility for the problem entirely with the workers themselves, ignoring the fact that the workers were acting in what they saw as the best interest of the restaurant by attempting to avoid overflowing toilets. The notice was not successful in stopping the appearance of toilet paper on the restroom floor. Because the owners had no plans to repair the plumbing and hence expected the busers to continue to clean flooded restrooms regularly, the kitchen workers were offended that their side of the problem had not been addressed. The threatening tone of the notice only complicated matters, and an employee tore the notice down after a few days. Eventually the managers held a meeting for all kitchen workers specifically to deal with the toilet paper problem. In the course of the meeting, the management finally agreed to bring in a plumber, and both problems (flooded restrooms and paper on the floor) were eventually resolved. The "toilet paper war" could have been resolved easily by responding to the busers' initial requests for plumbing repairs. The busers' recommendations were not taken seriously (or perhaps even listened to) until the situation had become something of a crisis. 
Because native speakers were often consulted in their production, written notices were more likely to succeed in terms of both their directive function and their referential function; that is, they were more likely to be understood than were verbal directives. However, the disregard for Spanish grammar indexes a negative evaluation of Spanish and Spanish speakers. The chiquitification of Spanish sets up unequal relationships between participants in an interaction. The disregard for Spanish grammar was typically accompanied by a disregard for Spanish speakers as cultural actors.

System for taking food orders. Disregard for Spanish grammar also resulted in problems with the computerized system for delivering food orders to the kitchen. Servers placed orders using a touch-screen computer with windows containing various options. When someone entered a table number, a screen would open with options such as BREAKFAST, SPECIALS, ENTREES. Touching the desired window would open a new screen listing particular menu items with MODIFY and DONE keys. The MODIFY key would lead to a screen of options including side orders and ingredients, with commands such as SUB (substitute), ON SIDE, NO (to remove a particular ingredient or side dish). All of the keys on the server screens were in English, with the exception of borrowed names of particular foods, such as enchilada. When the server placed an order, the computer printed a "translated" version in the kitchen so that the order could be prepared. The translations were entirely based on one-to-one correspondences, so that each English key corresponded to a specific Spanish output. Some of the translations included obvious grammatical errors. For example, ON SIDE was translated as ALADA (literally 'winged') rather than actual Spanish AL LADO 'on the side'. Although there were several exceptions, content words were generally left in English and function words were typically translated into Spanish, as in the example below:

(23) Sample order ticket

$\begin{array}{ll}\text { Server input } & \text { Kitchen output } \\ \text { TACO PLATE } & \text { TACO PLATE } \\ \text { 2 STEAK } & \text { 2 STEAK } \\ \text { WITH } & \text { CON } \\ \text { CHEESE } & \text { CHEESE } \\ \text { WITH } & \text { CON } \\ \text { GUAC } & \text { GUAC } \\ \text { CORN } & \text { CORN } \\ \text { NO } & \text { SIN } \\ \text { RICE } & \text { RICE } \\ \text { GUAC } & \text { GUAC } \\ \text { ON SIDE } & \text { ALADA } \\ \text { TO GO } & \text { TO GO }\end{array}$

As with other forms of directives, the disregard for Spanish grammar has led to the production of directives that are not easily interpreted. The (English) server 
screen contained distinct keys for WITH, SUB, and ADD. However, in the kitchen output, all of these terms were translated as CON (literally 'with'). The distinctions between the three command keys were often crucial to intended meaning:

(24) WITH - add an ingredient that doesn't cost extra

SUB - remove the expected ingredient or side and replace it with another item

ADD - add an item that costs extra

In the kitchen printout, orders using SUB or ADD were indistinguishable from those using WITH (all appearing as CON). For servers, the distinction between ADD and WITH was a question of price. ADD would be used to add more of an ingredient that was already included in the item (such as adding extra meat to a taco). In contrast, WITH meant to add ingredients that did not add to cost (such as adding lettuce to a taco). When ADD was used to increase a particular ingredient, the resulting kitchen order (translated as CON) could be illogical or confusing. For example OMELETTE ADD EGG was translated as OMELETTE CON HUEVO 'omelette with egg'. Since all omelettes contain eggs, an order for "omelette with egg" was entirely redundant and provided no suggestion that the server was actually requesting an omelette made with four eggs instead of three. Failure to add the additional ingredient was typically interpreted as the result of conscious neglect or "stinginess" on the part of the kitchen staff.

Similar problems arose with the use of the SUB command (also translated as CON). Servers usually assumed that the item to be removed in a substitution would be obvious unless specified. When substituting black beans for refried beans on a dish that was always served with refried beans, for example, adding SUB BLK BN ('substitute black beans') presupposed that the reader knew that the black beans replaced refried beans rather than rice or cheese, for example. The order would be translated as CON BLK BN 'with black beans', giving no indication that an actual substitution was involved. The common mistake resulting from this translation error was for the cook to add вотн types of beans to the dish, a logical interpretation of the translation. These substitution errors were typically seen as resulting from the kitchen staff's being lazy by not reading tickets correctly, simply being "stupid," or consciously making things difficult for the server (sometimes owing to real or imagined animosity between particular individuals). As with verbal directives, the system for placing orders limited the ability of Spanish speakers to perform their job duties successfully and thus receive positive evaluations of their actions from co-workers and managers.

\section{LATINO USE OF SPANISH AT CHALUPATOWN}

\section{Fulfilling directives one doesn't understand}

Because failure to respond to directives was usually blamed on the Spanishspeaking employee, repeated failure to respond properly could lead to losing one's job. Asking for clarification often resulted in reprimand from the manager, and so some employees asked for more explicit or clearer instructions only as a 
last resort. Reprimands ranged from verbal admonishment to being fired. Failure to fulfill a directive typically resulted in scolding from a manager, but repeated failures to comply (or a single serious failure) could result in being "written up" or losing one's job.

Spanish-speaking employees had several mechanisms for coping with the continual demand to follow directives they did not understand. These strategies included extensive training, seeking clarification from more senior Spanishspeaking employees, and seeking the help of a bilingual.

Spanish-speaking employees took a very careful approach to employee training. Training of English-speaking employees usually consisted of one day of "shadowing" the trainer, followed by a day in which the trainee would do the majority of work under the trainer's supervision. Tasks of sporadic or rare occurrence (such as servers' placing specially modified food orders or bartenders' changing the carbon dioxide tanks for soft drinks) were usually not covered during the training of English-speaking employees. It was generally understood that when such needs arose, the employee could simply ask a manager for instructions. In contrast, the Spanish-speaking employees recognized that newly trained employees would need to know about ALL possible tasks (including relatively rare ones) because it was likely that they would never receive clear instructions from managers. Because of this difference in access to information, the initial training for Spanish speakers included details concerning locations for storing utensils and putting away shipments, including things that were rarely used.

In cases where a manager's directive involved something that hadn't been covered in training, employees would usually seek clarification from a more senior Spanish-speaking employee. Because most of the cooks had previously worked as dishwashers or busers, they were often familiar enough with other jobs in the restaurant to help the newer employee determine the meaning of a particular directive. In these cases, the newer employee would explain his limited understanding of a directive and request elaboration. Managers would sometimes use kitchenware or tools as a visual aid when giving verbal directives, and newer employees would simply carry the tool to a more senior employee and ask, "What am I supposed to do with this?" This means of seeking advice was the most common response to interpreting directives involving tasks that had not been covered in training.

Employees faced with directives they did not understand would also ask for help from a bilingual co-worker if one were readily available. In cases of very rare or highly specific directives, other monolingual employees often were also unable to interpret a particular directive, and looking for a bilingual was the employee's only option before returning to the manager and possibly facing a reprimand. Monolingual Spanish-speaking employees would typically try to remember the English content of directives in order to be able to ask a bilingual to translate a particular word or phrase so they could fully understand the directive in question. For example, I had the following interaction with a buser trying to 
interpret a directive - which must have been something like "We need more soap in the baño" - without knowing the English word soap (having heard English [sowp] as [su:p]).

(25) Buser: ¿Que quiere decir "soup” [su:p] ?

'What does "soup" mean?'

Rusty: "Caldo" o "sopa"

" "Caldo" or "sopa",

Buser: No... [pause] es algo que se pone en el baño.

'No ... it's something that goes in the restroom.'

Rusty: Ah, "soap" - quiere decir "jabón."

"Ah, "soap" - it means "jabón.",

On occasions when the Spanish-speaking employee could not remember the English content of a directive or when the directive had absolutely no retrievable Spanish content, even bilingual co-workers were unable to help. In these cases, the Spanish-speaking employee was only able to ask very general questions, such as "What does she want me to do?" These cases were most likely to result in the Spanish-speaking employee's returning to the manager for clarification. Employees were aware that a longer time spent trying to understand a directive would result in being scolded for not having fulfilled the directive promptly. Occasionally, employees would ask a bilingual to go to the manager directly and explain that the Spanish speaker did not know what was expected of him. Even if the bilingual were willing to intervene, this did not mean that a reprimand was always avoided: The manager would sometimes scold the employee both for not fulfilling the directive and for interrupting the bilingual's regular work.

\section{Spanish as a marker of solidarity}

The majority of Anglo workers did not generally pay attention to conversations between Spanish speakers in which no Anglos were involved. Latino workers were thus able to vent frustrations and negative assessments of co-workers fairly openly. Discussions about issues of racism, exceptionally rare in English, were quite common in Spanish. English-language discussions about race almost universally involved stereotyped assessments of customers or negative attitudes toward Latino co-workers. In contrast, Spanish-language discussions often dealt with racist attitudes of individual English-speaking workers or the general problem of racism in the restaurant.

Spanish-speaking workers would regularly discuss which co-workers were seen as racistas 'racists' and which were buena gente 'good people'. These discussions were generally framed as a mechanism for improving working conditions by alerting co-workers to avoid potential problems by avoiding interactions with potential racistas. Discussions of the possible racist attitudes of individual co-workers, especially managers, allowed workers to warn one another in order to avoid problematic interactions that might result in arguments. Because it was generally recognized that requests made to a racista were unlikely to be fulfilled, these discussions improved workplace efficiency by alerting workers to 
which Anglo co-workers were cooperative and which were more likely to complicate interactions because of their racist attitudes (cf. Lindeman 2002). New workers were often highly conscious of the racista and buena gente categories, frequently asking about different co-workers in order to learn which ones were best avoided.

Anglo co-workers most widely recognized as racistas were those who had repeatedly reprimanded or yelled at Spanish-speaking workers for minor infractions, particularly those that would typically go unmentioned if committed by an English-speaking worker. As is often the case with managers who are viewed as mean or unfair, employees would alert one another when the manager was present in the workplace. It should be noted that the two most prominent racistas were also negatively viewed by Anglo employees, suggesting that a more generally abrasive personality could contribute to the perception of one as racista.

Neither group of employees, Anglo nor Latino, generally knew the names of all the co-workers from the other group. Anglo workers did not generally talk about or interact with specific Latino employees enough to learn their names. In contrast, Spanish-speaking employees generally developed Spanish nicknames for many of the Anglo employees. This may be partially due to the difference in job duties. A server makes requests to the kitchen as a whole, while kitchen workers fill requests for specific servers. A server would not generally know who was preparing his or her order, but kitchen workers would know exactly which servers placed each order they prepared. Some of the nicknames referred to an individual's disposition or personality, such as La Loca 'the Crazy Woman' or El Joto 'the Fag', (offensive). More typically, they referred to an individual's physical characteristics, like Pelón 'Baldy', La Gordita 'the Chubby Woman', or Nalgona 'the Woman with a Big Butt' (offensive). Because nicknames were most common for Anglos who did not interact with Latino co-workers, most Anglos referred to by nicknames did not realize that they even had them.

Nicknames were regularly used to discuss racista co-workers openly in Spanish even when the manager in question was present. One manager who was relatively short in stature was nicknamed Culerín 'Little Asshole' (offensive). Another manager who frequently came to work high and took breaks to smoke marijuana behind the building was nicknamed El Chinito 'the Little Chinese Man' because he always kept his eyes squinted under the bright lights of the kitchen.

Although Anglo fears of Spanish being used in insults were generally exaggerated, Spanish-speaking employees would sometimes conduct negative appraisals of an Anglo co-worker in the co-worker's presence. Sometimes, mocking comments in Spanish would be directly addressed to an Anglo worker with the knowledge that the addressee was unlikely to understand what was being said.

Bilingual workers would also use code-switching to exploit the pragmatic potential of Spanish (cf. Valdés 1981). Switching into Spanish in a conversation with monolingual English-speaking participants might be used to exclude Ang- 
los from the conversation. In the following example, the server Carmen (one of the two bilingual servers) uses Spanish to taunt the manager Culerín by hinting that he is the topic of the Spanish conversation. Culerín is managing the bar and thus has supervision over me, but not over Carmen. When the interaction begins, I am preparing drinks for servers and Carmen approaches to see if her order is ready. She begins talking about Culerín in Spanish while he is not present, but continues talking about him (to me in Spanish) after he approaches and attempts to enter into the conversation.

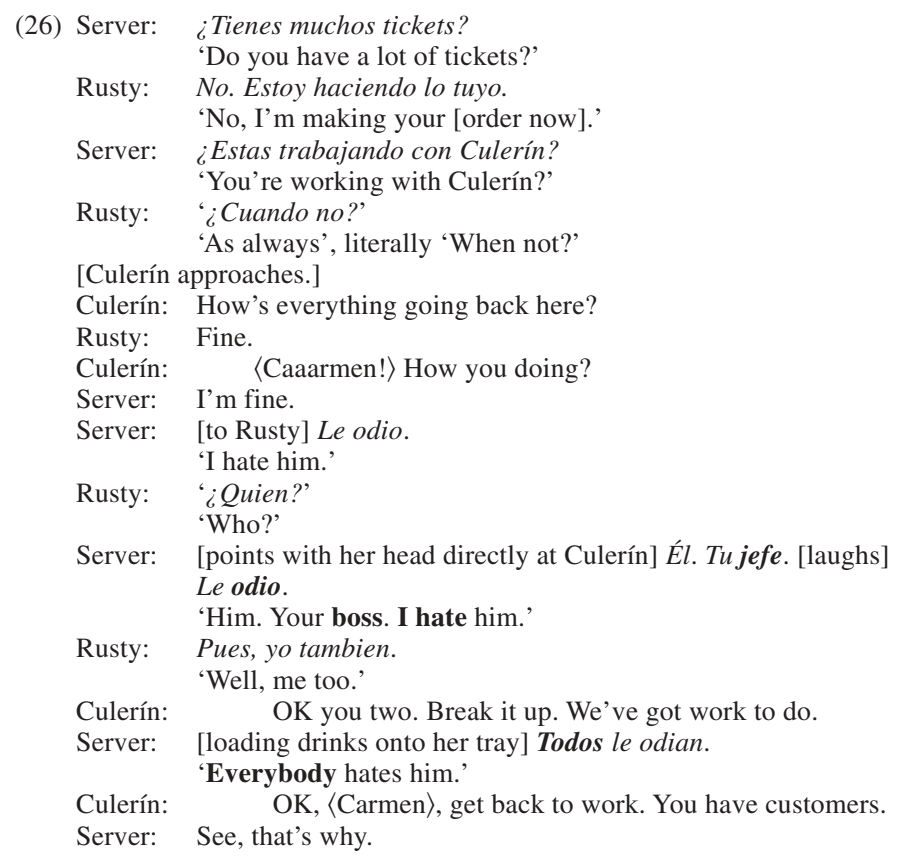

After a minimal phatic response to Culerín in English (I'm fine), Carmen returns to Spanish, telling me that she hates Culerín even though he has tried to start a conversation with her in English. When I ask whom she is referring to, she points her head at Culerín and says él (3rd singular pronoun). Carmen raises her voice and adds emphatic pitch accent when she says él and tu jefe, both Spanish phrases Culerín is likely to understand. Culerín begins by trying to initiate a friendly conversation with Carmen in English, but quickly moves to a managerial stance. Culerín's reaction, telling us to stop talking and return to work, suggests that he has gotten the hint. His reaction is understandable, since directly telling us not to talk about him in Spanish might convey insecurity or paranoia on his part.

After Carmen continues in Spanish, Culerín tries again to halt the Spanish conversation by telling her again to return to work, despite the fact that he is technically not her supervisor. Servers regularly complained about the fact that 
Culerín would try to tell them what to do even when he had no supervisory power over them. Carmen switches into English for her final comment to me, see, that's why, referring to the fact that Culerín has overstepped his job duties by acting like her boss. The switch into English as she walks away makes it fairly clear that Culerín was indeed the topic of our Spanish conversation without giving him an opportunity to respond.

Here Carmen is able to turn the tables and use Spanish in order to restrict the agency of Culerín. She drops hints about the referential meaning so that Culerín may recognize that he is the topic of the conversation. Because the conversation is in Spanish, Culerín is unable openly to express evaluation of the interaction or defend himself. He resorts to a position of relative power by taking a managerial stance in an attempt to end the conversation altogether.

Sometimes, mocking comments in Spanish would be directly addressed to an Anglo worker with the knowledge that the addressee was unlikely to catch all of what was being said. Most of the time, humor at the expense of Anglo coworkers went entirely unnoticed. On one occasion, a manager who was having a particularly bad hair day told me that she had been receiving compliments from the kitchen staff. She said, "The cooks told me I looked really pretty today. They said they liked my hair." Somewhat bewildered, given the state of her hair, I simply said "That's nice" and remained silent. After a short pause, the manager asked, "Hey, what does escoba ['broom'] mean?" Clearly she had not understood the sarcastic nature of the cooks' compliments. Thus, although the irrelevance of Spanish for managers made work more difficult for Spanish speakers, it also made it possible openly to vent frustrations and criticisms without sparking reprimands from managers.

\section{Spanish as a tool of resistance}

Anglo language ideology at Chalupatown constrained the agency of the Latino workers in English-dominated contexts, but the Anglo disregard for Spanish also made it possible for Latino workers to use Spanish to develop an alternative linguistic market. Although kitchen workers had control over very few resources in the restaurant, the Anglo disregard allowed kitchen workers to use Spanish to exert control over the limited resources available to them. Because the owners were concerned about theft by employees, many of the resources workers required to perform their jobs were kept in locked cabinets that could be opened only by a manager. Servers would regularly hide resources such as pens, credit card trays, and aprons to make sure that they could get them without help from a manager. For bartenders, hosts, and kitchen workers, garbage bags were the most difficult resource to obtain.

Although garbage bags were mostly used by busers and cooks, bartenders and hosts required them as well. Garbage bags were most needed toward the end of a shift, when managers were usually extremely busy and unlikely to stop and unlock the cabinet containing garbage bags. As it could take up to half an hour 
just to find a manager willing to open the cabinet, garbage bags took on great value for the workers who needed them. Some managers would occasionally give out an entire roll at once, since opening the cabinet repeatedly while trying to close the restaurant was impractical. Others would never give out more than one or two bags at a time. Because one never knew when the chance to get more bags would come around, workers would hoard garbage bags and hide them from other employees. I was actually told about the importance of hiding surplus garbage bags as part of my initial training as a bartender. Disputes over garbage bags were a regular occurrence, and workers would regularly change the secret location of their bags to keep them from being taken by other workers.

Because busers used many more bags than other employees, managers were more likely to fulfill their requests for an entire roll. Busers working day shifts would often save bags for those working at night and let them know where they were hidden. Busers were able to maintain the largest garbage bag stockpile in the restaurant and would usually share the location with other Spanish-speaking workers. Because I often worked shifts that overlapped with morning and evening buser schedules, the morning busers would often tell me the location of garbage bags (in Spanish) so that I could inform the busers working the night shift. Spanish speakers thus had better access to bags than English speakers and were less likely to end up in conflicts when they needed a bag. The option of simply asking where the bags were located was not available to other bartenders who did not speak Spanish regularly (i.e., those who used Spanish only for requests and directives). The busers would sometimes tease bartenders in Spanish rather than tell them where the bags were. For example, another bartender in search of bags once told me, "The bags are in the escondidas, wherever that is." (escondidas 'hidden', feminine plural)

Bartenders were often told they could leave as soon as the garbage had been taken out. If there were no bags, this might mean that the bartender would leave work late simply because of the time wasted searching for bags. If a bartender became frustrated trying to find bags, the access afforded by speaking Spanish took on real value, because busers would sometimes insist that bartenders give beer to all the kitchen workers in exchange for a few garbage bags.

Because of the division of labor along racial lines, Latino workers also had more direct access to food within the restaurant. At Chalupatown, servers could order food at half price, while bartenders, hosts, and kitchen workers received one free meal for each shift that they worked (excluding several of the higherpriced menu items). Because the Latino employees worked in the kitchen, they could prepare whatever they wanted with the ingredients available, while Anglo employees usually had to order from the menu. During periods when business was relatively slow, the cooks would sometimes prepare a large amount of a special dish for all of the kitchen workers. Word would spread around the restaurant in Spanish, so that the cooks could get an idea of how much food to prepare. The Anglo workers tired of eating off the same menu five days a week would 
often complain, "Why can't we get that?" When two of my Anglo co-workers realized that I was regularly asked if I wanted a serving, they asked if I could help "get them on the list."

Spanish also provided different access to food because of interactions with the delivery drivers for produce companies. The drivers all spoke Spanish and would sometimes leave gifts of fruit for the kitchen staff. Sometimes drivers or employees themselves would bring pastries for other workers. In the summer, the produce driver would leave a watermelon once every week or two. A group of Anglo servers once took the watermelon for a party to which kitchen workers were not invited. After this, the kitchen staff began to hide the watermelon in the cooler. As with specially prepared dishes, news that the watermelon was about to be cut or that pastries were available would spread through the restaurant in Spanish, making it unlikely that Anglos would be able to partake. Although the resources involved were fairly petty items like garbage bags and watermelons, kitchen workers were able to use Spanish to control the resources that were available to them.

\section{Pretending not to understand}

Another way in which Spanish allowed for resistance in the workplace was the possibility of pretending not to understand a directive. Because Anglo employees typically made little effort to make themselves understood in Spanish, Latino workers generally had that option. This strategy was not widely used and would not be effective in many cases owing to an assumption of comprehension by managers (cf. ex. 14 above). Contrary to the assumption of Anglo managers, Spanish-speaking workers would rarely if ever use this strategy to avoid their actual work responsibilities. Pretending not to understand was most frequently used to avoid conflict in cases where an Anglo employee asked a kitchen worker to violate workplace rules. Some of the Anglo employees would regularly try to get kitchen workers to perform tasks for them, as in the example of refilling the ice bin. For several weeks, some Anglo servers would pay busers extra money to perform what should have been the servers' own side work (e.g., sweeping their section, refilling salt and pepper shakers). This practice was prohibited after the managers were forced to stay late one night, waiting for two busers to perform the side work ten different servers had paid them to do. Other examples in which servers might make special requests include asking for food items without ringing them in on the register, requesting larger helpings, and asking busers to pour water and tea for customers. In these cases, pretending not to understand was a viable strategy because the Anglo employees were aware that they were asking a co-worker to break the rules and would not generally press the issue. Although Anglos typically assumed that kitchen workers pretended not to understand a wide range of directives, this strategy was actually used most frequently in cases where Anglos were both trying to exploit Spanish-speaking co-workers and violating workplace rules. Pretending not to understand blocked Anglo attempts to 
assert control over the actions of Spanish-speaking employees, but it also reinforced the Anglo perception that Spanish speakers understood English more than they let on.

Another Anglo bartender was telling me his reasons for quitting his job at Chalupatown and looking for other work. We worked together quite often and were good friends. He explained that the environment at Chalupatown was increasingly stressful for him, and that he had fallen into a deep depression and just couldn't take it anymore. I certainly understood, but as I came to have fewer and fewer Anglo co-workers I could talk to, I didn't want him to leave. "But see," he told me, "you speak Spanish well enough to escape. You can walk into the kitchen and talk to those guys for five minutes and remind yourself that the entire planet isn't populated with assholes. I don't speak Spanish that well. I don't have anywhere else to go." Although his comment reflects the central role of language in constructing social space within the restaurant, it is overly simplistic. The Anglo workers were not simply "assholes" or even "racists." Indeed, most of the Anglo managers presented themselves as explicitly ANTI-racist. The Anglo use of Spanish reproduces the prevalent norm for using Spanish to project a particular Anglo identity. In interactions with Spanish speakers, this Anglo appropriation of Spanish reproduces contexts of racial inequality, even though the use of Mock Spanish may not be consciously intended as racist.

The Spanish elements in Anglo directives may be fairly arbitrary (as in "You have to finish todo eso") so that they provide little help in actually conveying the information the directive requires. However, there are certainly some cases where the Spanish words would be helpful in conveying meaning. Saying that there is "agua on the piso" would certainly convey more information than "water on the floor." Some Spanish is better than none at all. ${ }^{6}$ Yet if the intent of including Spanish was actually to convey directives to Spanish speakers, one would expect the managers to utilize Spanish to the full extent of their competence and actually form Spanish sentences.

Although Anglo speakers had some knowledge of Spanish grammar, they rarely utilized this knowledge when communicating with a monolingual Spanish speaker. The intent behind this limited use of Spanish seems to be the same motivations Hill associates with some speakers of Mock Spanish: an attempt to convey congeniality and open-mindedness. Hill (1998:683) views Mock Spanish as part of Cmiel's (1990) "middling style," or "a way for elites to display democratic and egalitarian sensibilities by incorporating colloquial and even slangy speech." This "congeniality" is constructed through indexing racist stereotypes of Spanish speakers, however, and it is very Anglocentric.

Although the language ideology of Anglo workers restricted the ability of Spanish speakers to perform their job duties, the Anglo disregard for Spanish 
made it possible for employees to develop an alternative Spanish linguistic market. Spanish served as a means to provide crucial information both within and outside the workplace, and as an outlet for discussing the racial attitudes of Anglo co-workers. Kitchen workers were able to use Spanish to control the few resources available to them. The Anglo disregard for Spanish also made it possible for kitchen workers to claim a communication failure in order to opt out of conversations in which Anglos made overt attempts to exploit their Latino co-workers.

The Anglo use of Mock Spanish in interactions with Latino workers at Chalupatown is not particularly different from Hill's examples of its use in AngloAnglo discourse. There is no accommodation to Spanish speakers. Anglo Spanish marks racial difference through self-directed humor associated with an assumption of racial superiority. Mock Spanish does not generally facilitate communication of referential meaning, and the Anglo side of the communicative burden may involve nothing more than demonstrating recognition of the racial difference inherent in a particular interaction.

For Anglo speakers, the use of Spanish indexes AFFECTIVE STANCE (Ochs 1996:411). Ochs argues that social identities are constructed by varying indexical displays of stance across different situations (1996:424). The use of Spanish by Anglo speakers attempts to entail a context in which Anglo speakers project a social identity that includes an awareness of Spanish and a recognition that one is interacting with a Spanish speaker. Given the iconic relationship between Spanish and race, Anglos often interpret the full use of actual Spanish - speaking Spanish rather than inserting Spanish words into English - as an indexical sign that conveys solidarity with Spanish speakers (hence my being labeled a "burrito"). By using a little Spanish rather than full Spanish, Anglo speakers may be attempting to index a sympathetic stance toward Latinos without actually indexing a position of equality or solidarity. This is, of course, an entirely Anglocentric view of the functions of Spanish.

For native Spanish speakers, the use of Spanish nonce borrowings in English does not index positive social affect but is simply interpreted as a poor effort at speaking Spanish. Spanish-speaking workers typically attributed Anglo Spanish either to a lack of speaker competence or to an unwillingness actually to speak Spanish. Occasionally, kitchen workers would complain about receiving incomprehensible directives from Anglos they knew spoke enough Spanish to make themselves understood. The structure of Anglo Spanish ignores the Spanishspeaking listener's ability to comprehend in favor of using Spanish primarily to exploit Anglo understandings of the indexical functions of Spanish.

Spanish thus serves distinct functions for different speakers. For many Anglo speakers, Spanish serves a metapragmatic function (Silverstein 1992). That is, Spanish functions primarily as an indexical sign that entails a particular contextof-occurrence. For Spanish speakers, Spanish serves a more basic pragmatic function as the primary language of communication. The racial iconicity of Spanish 
for Anglo speakers impedes the communicative function of Spanish and excludes Spanish speakers from fully participating in interactions with Anglos.

Because Anglos use Spanish primarily for its presumed ability to index positive social stance, the ability of Spanish to serve its basic communicative function is diminished. The resulting limitations on the use of Spanish leave Spanish-speaking workers with a diminished ability to participate fully in interactions with Anglos. This interactional limitation constrains the agency of Spanish speakers. The ability for one's actions to affect others (and oneself) is diminished because the Spanish speaker does not have access to information that is vital to the evaluation of his or her actions. The language ideology of Mock Spanish serves directly to enact systematic conditions of racial inequality.

The interactions at Chalupatown suggest that the ideology of "white public space" (Hill 1998) is not restricted to public discourse and media representations. Language ideology plays an important role in maintaining racial inequality at many different levels. Mock Spanish allows Anglo speakers to assume that they have successfully indexed a positive social stance toward Latinos without their actually making a reasonable attempt to make themselves understood by monolingual Spanish speakers. The appropriation of Spanish is primarily selfserving. When the primary function of Spanish is to index a particular Anglo ethnic stance, Anglo speakers cease to recognize the more critical role of Spanish as the only language spoken by their interlocutors.

Anglo discussions of race at Chalupatown are often examples of the type of projection found in color-blind racism (Bonilla-Silva \& Forman 2000, BonillaSilva 2002). Servers give inferior service to Latino customers and then understand their low tips as resulting from the fact that Latinos are "cheap" rather than from the poor service itself. Managers assume that their directives aren't fulfilled because Latino employees are "lazy" rather than because the directives themselves were confusing. The circular logic that Anglo employees use to "explain" racial difference in their everyday experiences with their Latino co-workers maintains systematic racism within the workplace. Anglo racism is erased as a possible problem, and blame is shifted to the victims of racism themselves.

Language ideology both reflects and enacts racial inequalities. In AngloAnglo interactions, Mock Spanish may function as a form of symbolic revalorization, reproducing derogatory racial portrayals of Latinos for Anglo amusement. When used in interactions with Spanish speakers, Mock Spanish serves to exclude Spanish speakers from interactions in which they should be active participants. The failure to listen to the needs of Latinos and the failure earnestly to attempt to communicate with Spanish speakers are not forms of symbolic revalorization, but are basic components of racial subordination. The ideology of Mock Spanish is not simply a media tool for reproducing negative stereotypes of Latinos, it is a basic component in the maintenance of racial inequality in the United States. 


\section{RUSTY BARRET T}

\section{NOTES}

* I am greatly indebted to the restaurant workers who shared their experiences and opinions with me. For helpful discussions and comments, I would like to thank Eriko Atagi, Mary Bucholtz, Elaine Chun, Erin Debenport, Jane Hill, Jennifer Palmer, Robin Queen, Otto Santa Ana, Teresa Satterfield, Keith Walters, Albert Zapata, and an anonymous reviewer.

${ }^{1}$ All examples from http://www.urbandictionary.com. Entries change regularly over time. The examples here were present on the website as of October 24, 2004.

2 "Chalupatown" and all other names in this article are pseudonyms.

${ }^{3}$ The numbers are approximate because of fluctuations resulting from frequent employee turnover.

${ }^{4}$ Menu quotes have been slightly altered to maintain anonymity.

${ }^{5}$ Food cost (not actual food prices) refers to the ratio of money spent on food to the income from food orders. A rise in food costs implies that food is leaving the restaurant at a higher rate, either through larger portions, failure to ring in items, or employee theft.

${ }^{6}$ For example, a Spanish-speaking friend working at a restaurant in Michigan was simply given a photocopy of fairly complex English instructions for operating an industrial dishwasher with the assumption that he could find someone to translate it for him.

\section{REFEREN C E S}

Ahearn, Laura (2001). Language and agency. Annual Review of Anthropology 30:109-37.

Austin, John L. (1962). How to do things with words. Cambridge, MA: Harvard University Press.

Bonilla-Silva, Eduardo (2002). The linguistics of color-blind racism: How to talk nasty about Blacks without sounding "racist." Critical Sociology 28:41-64.

, \& Forman, Tyrone (2000). "I'm not racist, but ...": Mapping White college students' racial ideology in the United States. Discourse and Society 11:50-85.

Bourdieu, Pierre (1991). Language and symbolic power. John B. Thompson (ed.), Gino Raymond \& Matthew Adamson (trans.). Cambridge, MA: Harvard University Press.

Bucholtz, Mary (2004). The appropriation of African American Vernacular English as European American youth slang. Paper presented at New Ways of Analyzing Variation (NWAV) 33, University of Michigan, Ann Arbor.

Cameron, James, \& Wisher, William, Jr. (1991). Terminator II: Judgment Day (James Cameron, director). Tri Star Pictures.

Chun, Elaine (2004). Ideologies of legitimate mockery: Margaret Cho's revoicings of Mock Asian. Pragmatics 14:263-89.

Cmiel, Kenneth (1990). Democratic eloquence. New York: William Morrow.

Duranti, Alessandro (2001). Performance and encoding of agency in historical-natural languages. In Kate Henning et al. (eds), SALSA 9: Proceedings of the Ninth Annual Symposium about Language and Society, Austin, Texas Linguistics Forum 44(2), 266-87. Austin: University of Texas Department of Linguistics.

(2003). Agency in language. In Alessandro Duranti (ed.), A companion to linguistic anthropology. Oxford: Blackwell.

Eble, Connie (2004). Slang. In Edward Finegan \& John R. Rickford (eds.), Language in the USA: Themes for the twenty-first century, 375-86. New York: Cambridge University Press.

Erard, Michael (1996). Models of Spanish and Spanish speakers in the political economy of Anglo Spanish. In Alice Chu et al. (eds.), SALSA IV: Proceedings of the Fourth Annual Symposium about Language and Society - Austin.

Flouton, Deanne K. (1991). Hotel/restaurant Spanish. Hispania 74:194-96.

Ferguson, Charles (1975). Toward a characterization of English foreigner talk. Anthropological Lingustics 17:1-14.

(1981). "Foreign talk" as the name of a simplified register. International Journal of the Sociology of Language 28:9-18.

Gal, Susan, \& Irvine, Judith (2000). Language ideology and linguistic differentiation. In Paul Kroskrity (ed.), Regimes of language, 35-84. Santa Fe, NM: School of American Research Press.

Gingràs, Rosario (1974). Problems in the description of Spanish-English intrasentential codeswitching. In G. A. Bills (ed.), Southwest areal linguistics. San Diego: San Diego State University, Institute for Cultural Pluralism. 
Gumperz, John (1982) (ed.). Language and social identity. Cambridge: Cambridge University Press.

Haviland, John B. (2003). Ideologies of language: Some reflections on language and U.S. law. American Anthropologist 105:764-74.

Hill, Jane H. (1993). Is it really "No Problemo"? In Robin Queen and Rusty Barrett (eds.), SALSA I: Proceedings of the First Annual Symposium about Language and Society - Austin. Texas Linguistic Forum 33:1-12.

(1995). Mock Spanish: A site for the indexical reproduction of racism in American English. Originally posted at University of Chicago Lang-cult site: http://www.cs.uchicago.edu/ discussions / 1-c (1998). Language, race and white public space. American Anthropologist 100:680-89.

Hymes, Dell (1974). Foundations in sociolinguistics: An ethnographic approach. Philadelphia: University of Pennsylvania Press.

Jakobson, Roman (1960). Concluding statement: linguistics and poetics. In Thomas Sebeok (ed.), Style in language, 350-77. Cambridge, MA: MIT Press.

Lindeman, Stephanie (2002). Listening with an attitude: A model of native-speaker comprehension of non-native speakers in the United States. Language in Society 31:419-41.

Lindquist, Julie (2002). A place to stand: Politics and persuasion in a working-class bar. New York: Oxford University Press.

(2004). Class identity and the politics of dissent: The culture of argument in a Chicago neighborhood bar. In Marcia Farr (ed.), Ethnolinguistic Chicago: Language and literacy in the city's neighborhoods. Mahwah, NJ: Lawrence Erlbaum.

Lippi-Green, Rosina (1997). English with an accent: Language, ideology and discrimination in the United States. London: Routledge.

Mesthrie, Rajend (2002). Mock languages and symbolic power: The South African radio series Applesammy and Naidoo. World Englishes 21:99-112.

Morgan, Marcyliena (2001). "Nuthin' but a G thang": Grammar and language ideology in Hip Hop identity. In Sonja Lanehart (ed.), Sociocultural and historical contexts of African American Vernacular English, 187-210. Amsterdam: John Benjamins.

(2002). Language, discourse and power in African American culture. New York: Cambridge University Press.

Muysken, Pieter (2000). Bilingual speech. Cambridge: Cambridge University Press.

Myers-Scotton, Carol (1993). Duelling Languages: Grammatical structure in code-switching. Oxford: Oxford University Press.

Ochs, Elinor (1996). Linguistic resources for socializing humanity. In John J. Gumperz \& Stephen C. Levinson (eds.), Rethinking linguistic relativity, 407-37. Cambridge: Cambridge University Press.

Perea, Juan (1995). Los olvidados: On the making of invisible people. New York University Law Review 70:965-91.

Perkins, Lisa, \& Milroy, Lesley (1997). Sharing the communicative burden: A conversation-analytic account of aphasic/non-aphasic interaction. Multilingua 16:199-215.

Peñalosa, Fernando (1981). Chicano sociolinguistics. Rowley, MA: Newbury House.

Poplack, Shana (1981). "Sometimes I'll start a sentence in Spanish y termino en español": Toward a typology of code-switching. Linguistics 18:581-618.

; Sankoff, David; \& Miller, Christopher (1988). The social correlates and linguistic processes of lexical borrowing and assimilation. Linguistics 26:47-104.

Ronkin, Maggie, \& Karn, Helen E. (1999). Mock Ebonics: Linguistic racism in parodies of Ebonics on the Internet. Journal of Sociolinguistics 3:360-80.

Santa Ana, Otto (1999). "Like an animal I was treated": Anti-immigrant metaphor in U.S. public discourse. Discourse and Society 10:191-224.

(2002) Brown tide rising: Metaphors of Latinos in contemporary American public discourse. Austin: University of Texas Press.

Smitherman, Geneva (1994). Black talk: Words and phrases from the hood to the amen corner. Boston \& New York: Houghton Mifflin.

Silverstein, Michael (1992). Metapragmatic discourse and metapragmatic function. In John Lucy (ed.), Reflexive language, 33-58. Cambridge: Cambridge University Press.

(1998). Language ideologies: Practice and theory. In Bambi B. Schieffelin et al. (eds.), The uses and utility of ideology: A commentary, 123-45 New York: Oxford University Press. 
Urciuoli, Bonnie (1996). Exposing prejudice: Puerto Rican experiences of language, race, and class. Boulder, CO: Westview.

Valdés, Guadalupe (1981). Code-switching as deliberate verbal strategy: A microanalysis of direct and indirect requests among bilingual Chicano speakers. In Richard P. Durán (ed.), Latino language and communicative behavior, 95-108. Norwood, NJ: Ablex.

Walters, Keith (1995). Contesting representations of African American Language. In Risako Ide et al. (eds.), SALSA III: Proceedings from the Third Annual Symposium about Language and Society - Austin, Texas Linguistics Forum 36:137-51. Austin: University of Texas Department of Linguistics.

Woolard, Kathryn A., \& Schieffelin, Bambi (1994). Language ideology. Annual Review of Anthropology 23:55-82.

Zentella, Ana Celia (1996). The "Chiquitafication" of U.S. Latinos and their languages, or: Why we need an anthropolitical linguistics. In Risako Ide et al. (eds), SALSA III: Proceedings of the third annual Symposium about Language and Society - Austin, Texas Linguistics Forum 36:1-18.

(Received 28 January 2004; revision received 4 January 2005; accepted 11 January 2005; final revision received 2 September 2005) 